\title{
Potential Application in Biocatalysis of Mycelium-Bound Lipases from Amazonian Fungi
}

\author{
Sandra P. Zanotto, ${ }^{*, a}$ Israel P. Romano, ${ }^{a}$ Líliam U. S. Lisboa, ${ }^{a}$ Sergio Duvoisin Jr., ${ }^{a}$ Mayra K. Martins, ${ }^{b}$ \\ Fabiana A. Lima, ${ }^{a}$ Soraya F. Silva ${ }^{a}$ and Patrícia M. Albuquerque ${ }^{a}$
}

\author{
${ }^{a}$ Laboratório de Biorgânica, Programa de Pós-graduação em Biotecnologia e Recursos Naturais da Amazônia, \\ Universidade do Estado do Amazonas, 69050-030 Manaus-AM, Brazil
}

${ }^{b}$ Centro de Biotecnologia do Amazonas, 69075-351 Manaus-AM, Brazil

\begin{abstract}
Neste trabalho foram avaliados 212 fungos isolados de plantas da Região Amazônica quanto ao potencial de aplicação em biocatálise como fornecedores de lipases ligadas ao micélio. Estes isolados foram submetidos a ensaios de atividade hidrolítica e sintética. Quando submetidos ao ensaio com o substrato tributirina, $87 \%$ dos isolados apresentaram atividade hidrolítica. Destes, $30 \%$ mostraram bom crescimento em meio líquido indutor de lipase, e foram submetidos à avaliação sintética em reações de esterificação e transesterificação em solvente orgânico. Os nove fungos que apresentaram os melhores desempenhos sintéticos foram avaliados quanto a sua enantiosseletividade na reação de resolução do $(R, S)$-2-octanol. O isolado UEA_115 foi o biocatalisador mais versátil, apresentando bom desempenho nas reações de esterificação (conversão > 90\%) e boa capacidade para a resolução do $(R, S)$-2-octanol (ee $29 \%$; $e e_{\mathrm{p}} 99 \%$; c $22 \%$; E > 200). Com este estudo foi possível demonstrar o grande potencial dos fungos amazônicos como fornecedores de lipases para biocatálise.
\end{abstract}

In this study, 212 fungi were isolated from Amazon region plants, aiming to obtain mycelium bound-lipase-producing biocatalysts. These isolates were submitted to hydrolytic and synthetic activity assays. When submitted to the tributyrine substrate test, $87 \%$ of the isolates showed hydrolytic activity. Of these, $30 \%$ showed good growth in lipase inducing liquid media and were submitted to evaluation of synthetic activity in esterification and transesterification reactions in organic solvents. The nine fungi which had the best synthetic activity were evaluated in the $(R, S)$-2-octanol resolution reaction, in order to verify the enantioselectivity of mycelium-bound lipases. The isolate UEA_115 was the most versatile biocatalyst, showing good performance in esterification reactions (conversion $>90 \%$ ) and good ability for the resolution of $(R, S)$-2-octanol $\left(e e_{\mathrm{s}} 29 \% ; e e_{\mathrm{p}} 99 \%\right.$; c 22\%; $\left.\mathrm{E}>200\right)$. Thus, this study has demonstrated the great potential of the Amazonian fungi as lipase suppliers for biocatalysts.

Keywords: fungi, Amazon region, mycelium-bound lipase, biocatalyst screening, biocatalysis

\section{Introduction}

In recent years, global concern regarding the impact of human actions on the environment has been growing. The implementation of the concept of sustainable development in several productive activities has become an urgent issue. Fortunately, biotechnology also offers an increasing potential to meet the global demands for processes and products in greater harmony with the sustainability concept. ${ }^{1,2}$ In this regard, one of the most promising tools in biotechnology is the field of applied biocatalysis,

*e-mail: sandrazanotto@pq.cnpq.br also referred to by some authors as biotransformation or enzymatic technology. ${ }^{2,3}$

The advantages of using enzymes as biocatalysts in industrial processes have been shown to be ever more evident. Great versatility of catalyzed reactions, mild reaction conditions, and regio, chemo and enantioselective natures are those most frequently mentioned in the literature. ${ }^{4}$ Such characteristics allow the enzymes to promote reactions that would be difficult to stimulate through conventional organic synthesis techniques. ${ }^{5}$ From the ecological point of view, the most important factor is that the high selectivity and efficiency of biological catalysts lead to reactions with few byproducts and less energy 
consumption, making enzymes a more environmentally 'clean' alternative than traditional chemical catalysis. ${ }^{6}$ Many industrial sectors are strong candidates to make use of these advantageous aspects of biocatalysts on a large scale, and many are already using. ${ }^{7}$

The finding that enzymes can be active in organic media has opened an immense field of applications, particularly for the fine chemicals pharmaceutical industry. The obtainment of enantiomerically pure drugs, with potentializing action, which also avoid the risks of using racemic mixtures, tragically illustrated by the case of thalidomide, is of great interest to the pharmaceutical industry. ${ }^{8}$ The use of enzymes (in particular lipases) for the synthesis of chiral drugs, has been well established for years, and biotransformations are now accepted as common methodologies in the preparation of this type of medicine. ${ }^{9}$ In fact, in recent years the application of biological systems (enzymes or whole cells) is cited as the most significant development in the field of synthetic chemistry. ${ }^{10}$ Optically active alcohols are extremely useful starting materials and intermediates in synthetic organic chemistry and in the pharmaceutical industry. The obtainment of enantiopure alcohols by biocatalytic reactions has attracted considerable attention. ${ }^{11-13}$

Many other fields in which biotransformation processes are already in use or, at least, in an advanced state of development can be cited: treatment of residual waters, bioremediation, biopolymers, tests for clinical diagnosis and biofuel production are among the most important. ${ }^{2,7}$ In some industrial sectors, it is possible to detect an incipient change in paradigm; the traditional chemical catalytic processes tend now to be gradually replaced by biocatalytic processes. This change meets not only the demands for taking advantage of the beneficial characteristics of the enzymes, but also the need to satisfy the growing desire for sustainable technology. ${ }^{14}$

The processes which use lipases are particularly attractive due to the versatility of the application of these enzymes. ${ }^{15}$ The various technological segments which employ them include the food industry (development of aromas and maturation of cheeses), detergents, and oil chemistry (hydrolysis of oils and fats, synthesis of surfactants), as well as applications in the treatment of oily residues originating from the leather and paper industries.

It is worth noting the use of lipases for obtaining medicines in their enantiomerically active forms. ${ }^{16,17} \mathrm{In}$ fact, lipases have been widely recognized as the most important group of biocatalysts for biotechnological applications. ${ }^{18-20}$ They have been used to catalyze hydrolysis, esterification, transesterification and interesterification reactions, with extreme process simplicity, higher quality of the final product and excellent yield. ${ }^{15}$ They have become so attractive for employment in biotransformation because: (i) they are stable in organic solvents; (ii) they do not require co-factors; (iii) they have wide specificity for substrates; and (iv) they exhibit high enantioselectivity. ${ }^{18,21,22}$

Although higher animals and plants also produce them, most lipases currently employed in biotechnological applications have been isolated from microorganisms, mainly fungi and bacteria. ${ }^{21,23}$ From the economic and industrial point of view, microorganisms present advantages over higher animals and plants as sources of lipases, due to the high cost of enzyme isolation from higher organisms ${ }^{24}$ since microorganisms grow fast and are easily handled. Commercial lipases of fungal origin are generally extracellular enzymes, although there is considerable evidence for the activity of myceliumbound lipases and their study has received attention in recent years. Lipases bound to the cell, both in fungi and in bacteria, also have great stability in organic solvents. ${ }^{23,25-27}$

The industrial demand for new sources of lipases has continued to stimulate the isolation and screening of new lipolytic microorganisms. ${ }^{23}$ The immense biological diversity in the Amazon region and the importance of fungi as enzyme sources, has led to the search for new biocatalysts with special characteristics and possibilities for application in biotechnological processes. ${ }^{16,28}$ The access to a wide range of lipase types has made them even more desirable for two additional reasons: $(i)$ from the large number of lipases cited in the literature, only the enzymes of a few species have been shown to be stable and have biosynthetic capacities suitable for routine use in organic reactions; and (ii) many important problems remain unsolved in the application of lipases in certain industrial processes..$^{29}$

Considering the need for production processes which are more committed to the ideal of sustainability, this study aims to contribute to the broadening of knowledge regarding the biotechnological potential of fungi from the Amazon region, particularly those isolated from flora, as potential mycelium bound-lipase sources for application in the field of biocatalysis. In this study, lipase-producing Amazonian fungi were tested for both hydrolytic and synthetic activities. Fungi performance on tributyrin and olive oil hydrolysis, as well as on synthetic reactions in organic solvent were examined. The synthesis of pentyl oleate and dodecyl linoleate by esterification and the formation of ethyl palmitate by transesterification were evaluated and the strains with higher synthetic activity were used for the resolution of $(R, S)$-2-octanol. 


\section{Experimental}

\section{Isolation and maintenance of fungi}

The plants used in this study were acquired from markets and fairs in Manaus, capital city of the state of Amazonas, Brazil. All solvents and reagents used in this work were of analytical grade, are commercially available and were used without further purification.

For the isolation of the endophytic microorganisms different plant species from the Amazon region were used: spiked pepper (Piper aduncum), manioc (Manihot esculenta), tucumã palm (Astrocaryum aculeatum), Brazil nut (Bertholletia excelsa), uxi (Endopleura uchi) and cocoa (Theobroma cacao). In the isolation of the endophytic microorganisms, different plant material (leaves, stems, roots, seeds and fruits) were washed in running water and then dried on paper. They were then submitted to surface disinfection by way of immersion in $70 \%$ alcohol, $2 \%$ hypochlorite, $70 \%$ alcohol and again in sterile distilled water. ${ }^{30}$ Fragments of the different plant tissues were transferred to Petri dishes containing potato-dextrose-agar (PDA) culture medium supplemented with the antibiotic tetracycline $\left(100 \mathrm{mg} \mathrm{L}^{-1}\right)$ and incubated at $28{ }^{\circ} \mathrm{C}$ for approximately four days. Following this period, growth of the endophytic microorganisms was verified on each of the plant materials analyzed and the fungi obtained were purified by way of cross-breeding in Petri dishes to obtain monospore cultures. This procedure was repeated twice in order to ensure the purity of the isolates. When necessary, dilution and seeding in culture medium were used to obtain isolated colonies. After purification, the isolates were stored in test tubes containing the culture medium (PDA) and kept in a cold chamber at $5^{\circ} \mathrm{C}$ until later use.

The isolation of the phytopathogenic fungi was carried out from the leaves and fruits of different plants: peach palm (Bactris gasipaes), tucumã palm (Astrocaryum aculeatum), Brazil nut (Bertholletia excelsa), aloe vera (Aloe vera), cocoa (Theobroma cacao), banana (Musa paradisiaca) and sugar cane (Saccharum sp.) that had lesions due to the presence of fungi. The material was washed in running water (to remove excess impurities) and then tissue fragments were removed from the transition region between the lesion and the healthy area. The explants were submitted to surface disinfection in $70 \%$ alcohol and $2 \%$ hypochlorite, followed by two washings in autoclaved distilled water. ${ }^{28,31}$ The fragments were placed on filter paper to remove excess water and transferred to Petri dishes containing the culture medium (PDA) supplemented with chloranphenicol $\left(250 \mathrm{mg} \mathrm{L}^{-1}\right)$. The dishes were then incubated at $28^{\circ} \mathrm{C}$ until the appearance of fungal hyphae (24-48 h). The fungi were purified as previously described, and stored in test tubes containing the culture medium PDA, and kept in a cold chamber at $5^{\circ} \mathrm{C}$ until later use.

The wood degrading fungi were kindly provided by professor Ademir Castro e Silva of UEA. The fungi were grown on Petri dishes containing malt extract agar media, and kept in a cold chamber.

\section{Hydrolytic assays}

The preliminary lipolytic screening was carried out according to the methodology described by Torres et al. ${ }^{23}$ with modifications. The medium used was composed of mycological peptone $\left(5.0 \mathrm{~g} \mathrm{~L}^{-1}\right)$, yeast extract $\left(3.0 \mathrm{~g} \mathrm{~L}^{-1}\right)$, agar $\left(10.0 \mathrm{~g} \mathrm{~L}^{-1}\right)$, and tributyrine (Sigma) added to give a final concentration of $0.1 \%(\mathrm{v} / \mathrm{v})$. After autoclaving the medium $\left(121{ }^{\circ} \mathrm{C}, 20 \mathrm{~min}\right)$ the mixture was emulsified by vigorous shaking for $15 \mathrm{~min}$, and after cooling to approximately $60^{\circ} \mathrm{C}$, the medium was transferred to Petri dishes and rapidly cooled. The agar concentration used for the tributyrine assay is in the range suggested by Lawrence (under $1.5 \%$ ), ${ }^{29}$ assuring adequate protein diffusion into the solid medium.

The inoculant to be tested was previously cultivated in PDA medium for 5-7 days at $28^{\circ} \mathrm{C}$. A disc of the solid medium containing the inoculant was placed in the center of a Petri dish with agar containing the medium with tributyrine. The dishes were incubated at $25^{\circ} \mathrm{C}$ for 14 days and the presence of a translucent halo around the disc was used to confirm the hydrolytic activity of the isolates tested. All assays were carried out in triplicate.

For the olive oil test the methodology described by Colen was adopted, with modifications. ${ }^{30}$ The solid medium was prepared with yeast extract $\left(0.5 \mathrm{~g} \mathrm{~L}^{-1}\right)$, mycological agar $\left(25 \mathrm{~g} \mathrm{~L}^{-1}\right),\left(\mathrm{NH}_{4}\right)_{2} \mathrm{SO}_{4}\left(5.0 \mathrm{~g} \mathrm{~L}^{-1}\right),\left(\mathrm{NH}_{2}\right)_{2} \mathrm{CO}\left(2.0 \mathrm{~g} \mathrm{~L}^{-1}\right)$, $\mathrm{MgSO}_{4} \cdot 7 \mathrm{H}_{2} \mathrm{O}\left(1.0 \mathrm{~g} \mathrm{~L}^{-1}\right), \mathrm{NaCl}\left(1.0 \mathrm{~g} \mathrm{~L}^{-1}\right)$, olive oil (10 $\mathrm{mL} \mathrm{L} \mathrm{L}^{-1}$, Sigma) and bile salts $\left(3.0 \mathrm{~g} \mathrm{~L}^{-1}\right.$, Difco). The medium was heated and then homogenized in a blender for $1 \mathrm{~min}$, to obtain a stable emulsion, followed by autoclaving at $121{ }^{\circ} \mathrm{C}$ for $15 \mathrm{~min}$. After cooling to approximately $60{ }^{\circ} \mathrm{C}$ the medium was transferred to Petri dishes for rapid cooling. The dishes containing the medium with olive oil were inoculated with a disc of around $7.0 \mathrm{~mm}$ diameter cut from the PDA medium culture. The dishes were incubated at $25^{\circ} \mathrm{C}$ for 10 days and the formation of a translucent halo around the fungi was used to confirm the hydrolytic activity of the isolates.

\section{Obtainment of fungal mycelia}

The fungi which gave positive results in the test with tributyrine were cultivated in synthetic liquid 
medium consisting of asparagine $\left(2.0 \mathrm{~g} \mathrm{~L}^{-1}\right)$, glucose (2.0 g L $\left.\mathrm{g}^{-1}\right), \mathrm{K}_{2} \mathrm{HPO}_{4}\left(1.0 \mathrm{~g} \mathrm{~L}^{-1}\right), \mathrm{MgSO}_{4}\left(0.5 \mathrm{~g} \mathrm{~L}^{-1}\right)$, thiamine hydrochloride (5.0 mg L-1; $\mathrm{Sigma}), \mathrm{Fe}\left(\mathrm{NO}_{3}\right)_{3} \cdot 7 \mathrm{H}_{2} \mathrm{O}$ $\left(1.45 \mathrm{mg} \mathrm{L}^{-1}\right), \mathrm{MnSO}_{4} \cdot \mathrm{H}_{2} \mathrm{O}\left(0.235 \mathrm{mg} \mathrm{L}^{-1}\right)$ and sunflower oil $(2.0 \% \mathrm{v} / \mathrm{v})$, Sigma), used to induce the production of lipases..$^{20}$ The medium was inoculated with four discs of approximately $7.0 \mathrm{~mm}$ diameter of culture in PDA medium and incubated at $28{ }^{\circ} \mathrm{C}$ for 9 days under orbital shaking (200 rpm). The fungal mycelium was collected from the culture medium by vacuum filtration, washed with distilled water and acetone, ${ }^{22}$ dried for $48 \mathrm{~h}$ in a desiccator until constant weight and ground to a powder.

\section{Synthetic assays}

After the selection of the fungal isolates which produced hydrolase in solid media, the synthetic activity of lipases produced by the selected fungi was evaluated through the monitoring of the synthesis of pentyl oleate and dodecyl linoleate by esterification, and the synthesis of ethyl palmitate by transesterification. All assays were carried out in duplicate.

The fungi which showed good growth in synthetic liquid media, i.e., which produced above $500 \mathrm{mg}$ of mycelium

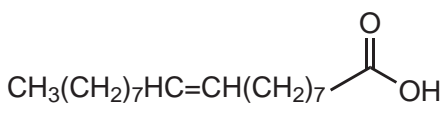

$\underset{\mathrm{CH}_{3}\left(\mathrm{CH}_{2}\right)_{4} \mathrm{OH}}{\stackrel{\text { mycelium }}{\rightleftharpoons \text { hexane }}}$

(dry weight) after nine cultivation days were selected for the synthetic screening. All synthetic reactions were carried out in organic media. Reactions performed in organic media eliminate microbiological contamination, since organic solvents are hostile environments for living cells. ${ }^{20}$

In order to study the synthetic activity of myceliumbound lipases, $50 \mathrm{mg}$ of mycelium were suspended in $n$-hexane (J. T. Backer, HPLC grade) containing equimolar amounts of fatty acid and alcohol for esterification reactions, and with an excess of one of the reagents for transesterification reactions. The reactions were incubated for $72 \mathrm{~h}$ under orbital shaking at $200 \mathrm{rpm}$ and $28{ }^{\circ} \mathrm{C}$. In the synthesis of pentyl oleate (Scheme 1), 6.66 mmoles of oleic acid and $n$-pentanol in $30 \mathrm{~mL}$ of solvent were used. To obtain the dodecyl linoleate (Scheme 2), 0.5 mmoles of linoleic acid and dodecanol in $10 \mathrm{~mL}$ of $n$-hexane were used. The transesterification reaction (Scheme 3) was carried out with $1.25 \times 10^{-2}$ mmoles of $p$-nitrophenyl palmitate (Sigma) and $5 \times 10^{-2}$ mmoles of ethanol in $10 \mathrm{~mL}$ of $n$-hexane.

The isolates which provided the greatest conversions to product in the synthetic reactions were evaluated in relation to their enantioselective activity. To this end, the $(R, S)$-2-octanol resolution reaction via transesterification

Scheme 1. Biocatalytic esterification reaction of oleic acid with $n$-pentanol for synthetic screening.

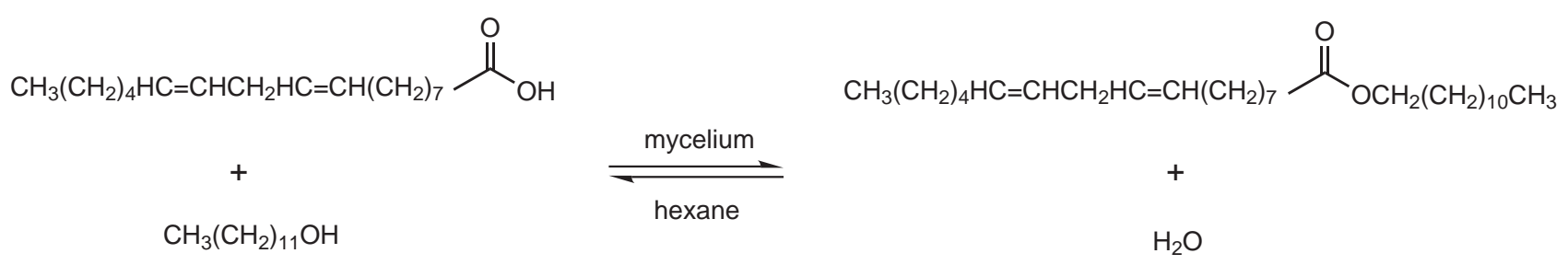

Scheme 2. Biocatalytic esterification reaction of linoleic acid with dodecanol for synthetic screening.<smiles>CCCCC(=O)Oc1ccc([N+](=O)[O-])cc1</smiles><smiles>CCCCCC(=O)OCC</smiles>

Scheme 3. Biocatalytic transesterification reaction of $p$-nitrophenyl palmitate with ethanol for synthetic screening. 


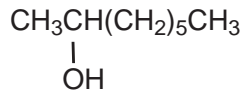

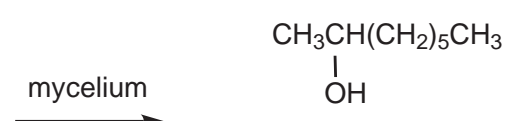

(R)-2-octanol or

(S)-2-octanol

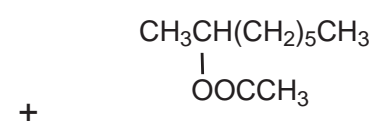

(S) 1-methylheptyl acetate

(R) 1-methylheptyl acetate

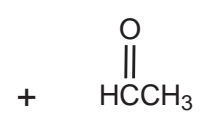

Scheme 4. Reaction of biocatalytic resolution of $(R, S)$-2-octanol with vinyl acetate for enantioselective evaluation.

with vinyl acetate (Scheme 4) was carried out. $50 \mathrm{mg}$ of mycelium in a solution containing 2.0 mmoles of $(R, S)$ 2-octanol and 6.0 mmoles of vinyl acetate in $10 \mathrm{~mL}$ of $n$-hexane were used.

In all biocatalytic reactions two control reactions were carried out: one containing only the reaction solution, without addition of mycelium (blank, B); and one where $50 \mathrm{mg}$ of the commercial enzyme Novozym 435 (lipase B of Candida antarctica, CAL-B) was added to the reaction medium (biocatalytic standard, S). Reactions containing only the fungal mycelium and organic solvent were also carried out in order to verify the occurrence of soluble by-products or cellular components in the reaction environment. These reactions were followed by thin layer chromatography (TLC, Merck) using hexane:ethyl acetate 9:1 as eluent. No spots appeared after $72 \mathrm{~h}$ of reaction.

\section{Analytical methodology}

Aliquots of the biocatalytic reactions were removed periodically and used for the determination of the percent conversion to product (\%c) and of the enantiomeric ratio (E). The conversions to pentyl oleate were obtained by nuclear magnetic resonance of hydrogen $\left({ }^{1} \mathrm{H}\right.$ NMR) (Varian Unity Inova AC $500 \mathrm{MHz}$ ) through the comparison of the integrals of the hydrogen singlets of the alcohol and the hydrogen atoms of the ester. ${ }^{34}$ On analyzing the ${ }^{1} \mathrm{H}$ NMR spectra for the alcohol and the ester a difference can be noted between the frequencies of the hydrogen peaks of the methylene group $\left(-\mathbf{C H}_{2}\right)$ bound to the oxygen atom, present in both molecules $\left(\mathrm{RCH}_{2} \mathrm{OH} ; \mathrm{R}^{\prime} \mathrm{COOC} \mathrm{H}_{2} \mathrm{R}\right)$. The hydrogen atoms of the methylene group of the alcohol gave peaks at a lower frequency (more shielded) than those of the ester (less shielded) in the ${ }^{1} \mathrm{H}$ NMR spectra. Due to this feature, through the integration of the areas of the spectra, the conversion of the esterification reaction can be calculated.

The conversions to dodecyl linoleate and ethyl palmitate were obtained by high performance liquid chromatography (HPLC, Varian ProStar 310, UV detector at $210 \mathrm{~nm}$, column Microsorb 300-5 C4 - $25 \mathrm{~cm}$, acetonitrile/water gradient) through comparison of the peak area of the ester produced by the fungi with the peak area of the ester produced by the commercial enzyme Novozym 435 (100\% conversion).

In order to compare the conversion values that were determined by different analytical methods ( ${ }^{1} \mathrm{H}$ NMR and HPLC), samples from the esterification reaction of linoleic acid with dodecanol were analyzed by the two techniques. Both analytical methods were shown to be adequate to determine biocatalytic reaction conversions, since a good correlation between the observed values $\left(R^{2}=0.976\right)$ was observed. ${ }^{35}$

The conversions to $(R)$ - or $(S)$-2-octanol were obtained by gas chromatography coupled to mass spectrometry (Shimadzu GCMS-QP2010) using a chiral stationary phase (Chirasil-Dex CB $25 \mathrm{~m} \times 0.25 \mathrm{~mm}$ ID $\times 0.25 \mathrm{~mm}$ ). Column temperature was $80{ }^{\circ} \mathrm{C}$. The He pressure was $56.9 \mathrm{kPa}$; and the temperatures of the injector and the detector were $220{ }^{\circ} \mathrm{C}$ and $275{ }^{\circ} \mathrm{C}$, respectively. The calculation of the enantiomeric ratio (E) was carried out according to the formula described by Faber. ${ }^{4}$ The values of the enantiomeric excess of the substrate $\left(e e_{\mathrm{s}}\right)$ and of the product $\left(e e_{\mathrm{p}}\right)$ were obtained through the peak areas of the enantiomers.

\section{Results and Discussion}

\section{Isolation of Amazonian fungi}

A total of 77 isolates were obtained from the endophytic fungi of fragments of six different plant species; 45 were isolated from phytopathogenic fungi growing on fragments of seven different plant species; and 90 wood degrading fungi were isolated from the stems of different species (Figure 1a).

As can be seen in Figure 1b, a greater number of phytopathogenic isolates from Brazil nut, tucumã palm and peach palm were obtained. In the case of endophytic fungi (Figure 1c), spiked pepper allowed the obtainment of the greatest number of isolates. Endophytic microorganisms (fungi and bacteria) are those that inhabit inside a plant for at least a period of its vital cycle, and are found in tissues such as leaves, branches and roots. Apparently, they do not cause any damage to the host, which distinguishes them from the phytopatogen microorganisms. Their 

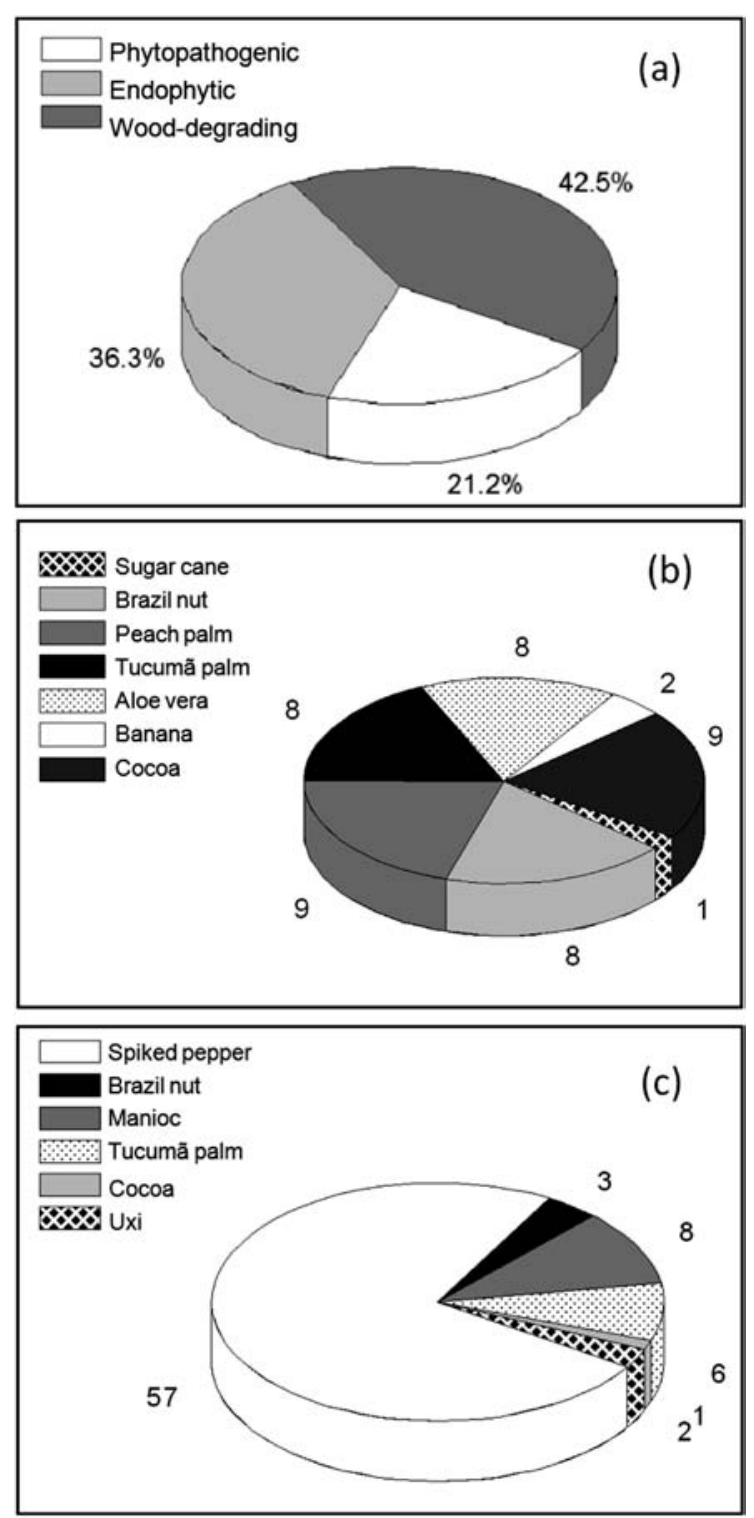

Figure 1. (a) Fungal isolates obtained from Amazon region plants; (b) Number of phytopathogenic isolates and their respective hosts; (c) Number of endophytic isolates and their respective hosts.

presence implies a symbiotic interaction in all the plants investigated until now. ${ }^{33}$ These microorganisms gained interest in the 1970's due to the possibility of producing pharmacologically active substances with biotechnological potential such as antitumor agents (Pestalotiopsis microspora, taxol) and antifungal agents (Cryptosporiopsis criptocandina, quercine), besides producing plant growth factors, toxins and enzymes. ${ }^{37-40}$

The 212 fungal isolates were stored in triplicate and transferred every three months to a new dish containing PDA medium in order to maintain the fungal cellular viability. The isolates were coded and the information relating to the origin of the organisms was grouped (Table 1).

\section{Hydrolytic screening}

The 212 fungal isolates were submitted to preliminary tests with tributyrine in order to evaluate the hydrolytic capacity. Of these, the isolates from 74 endophytic, 41 phytopathogenic and 70 wood degrading fungi showed the formation of a halo, indicating the production of hydrolases, that is, $87 \%$ of the Amazonian fungi evaluated in this study produced enzymes with hydrolytic activity. This result indicates the great potential of these species as a source of microorganisms which produce hydrolytic enzymes.

Of the species, spiked pepper, Brazil nut, uxi and cocoa, $100 \%$ of their endophytic isolates produced halos. Of the endophytic isolates of tucumã palm and manioc, 83 and $75 \%$, respectively, showed a positive result. Of the total of 77 endophytic isolates, $96 \%$ produced halos in the presence of tributyrine.

Among the phytopathogenic fungi evaluated, peach palm, the fruit of which had around $20 \%$ oil in its composition, ${ }^{41}$ provided isolates with $100 \%$ halo appearances, as much as the isolates from aloe vera. Of the phytopathogenic fungi isolated from Brazil nuts (which have good proportions of unsaturated fatty acids, $75.6 \%)^{42}$ and tucumã palm, $87.5 \%$ showed hydrolytic activity and $71 \%$ of the isolates from cocoa presented positive result. Of the 45 phytopathogenic fungi evaluated, $89 \%$ produced halo when cultivated on tributyrine.

Within the 90 wood degrading fungi evaluated, 70 showed the production of hydrolases, which represents $78 \%$ of these isolates.

Studies involving the screening of microorganisms as sources of lipolytic enzymes frequently describe carrying out a preliminary selection of the hydrolytic activity associated with the strains..$^{23,26,29,32}$ The initial selection for the detection of a particular activity has a significant weighting in the screening process, since it aims to eliminate the worst candidates and, in general, is carried out through the cultivation of microorganisms in a solid culture medium, in Petri dishes. ${ }^{44}$

Triacylglycerides such as triolein or -butyrin are used as standard substrates for the determination of lipase activity. ${ }^{4}$ Tributyrine is the substrate which has been most used for detection of lipolytic activity. ${ }^{23,29,32,45}$ On being hydrolyzed, tributyrine generates dibutyrine, monoburytine, glycerol and butyric acid, all of which are soluble in water, facilitating the visualization of the translucent halo. ${ }^{32}$ Despite the drawbacks associated with the use of tributyrine (since it is not a specific substrate for lipases as it can also be hydrolyzed by esterases), this is a convenient substrate, since it can be dispersed in water by agitation, without the need to add emulsifiers. ${ }^{46}$ Some authors have also recommended the use 
Table 1. Identification code for isolated Amazonian fungi and their respective origin

\begin{tabular}{|c|c|c|c|c|c|c|c|}
\hline Strain Code & Type $^{a}$ & Host & Tissue & Strain Code & Type & Host & Tissue \\
\hline UEA_001 & PT & B. excelsa & seed & UEA_107 & $\mathrm{EF}$ & M. esculenta & stem \\
\hline UEA_002 & PT & A. aculeatum & fruit & UEA_108 & FT & A. vera & leaf \\
\hline UEA_003 & WD & Amazon wood & stem & UEA_109 & $\mathrm{EF}$ & M. esculenta & leaf \\
\hline UEA_004 & WD & Amazon wood & stem & UEA_110 & WD & Amazon wood & stem \\
\hline UEA_005 & WD & Amazon wood & stem & UEA_111 & WD & Amazon wood & stem \\
\hline UEA_006 & PT & T. cacao & fruit & UEA_112 & WD & Amazon wood & stem \\
\hline UEA_007 & PT & T. сасао & fruit & UEA_113 & WD & Amazon wood & stem \\
\hline UEA_008 & PT & A. aculeatum & fruit & UEA_114 & WD & Amazon wood & stem \\
\hline UEA_009 & WD & Amazon wood & stem & UEA_115 & WD & Amazon wood & stem \\
\hline UEA_010 & PT & B. gasipaes & fruit & UEA_116 & WD & Amazon wood & stem \\
\hline UEA_011 & PT & A. vera & leaf & UEA_117 & WD & Amazon wood & stem \\
\hline UEA_012 & PT & A. vera & leaf & UEA_118 & WD & Amazon wood & stem \\
\hline UEA_013 & PT & T. cacao & fruit & UEA_119 & WD & Amazon wood & stem \\
\hline UEA_014 & PT & B. excelsa & seed & UEA_120 & WD & Amazon wood & stem \\
\hline UEA_015 & PT & A. aculeatum & fruit & UEA_121 & WD & Amazon wood & stem \\
\hline UEA_016 & PT & B. gasipaes & fruit & UEA_122 & WD & Amazon wood & stem \\
\hline UEA_017 & PT & B. gasipaes & fruit & UEA_123 & WD & Amazon wood & stem \\
\hline UEA_018 & PT & A. vera & leaf & UEA_124 & WD & Amazon wood & stem \\
\hline UEA_019 & PT & A. vera & leaf & UEA_125 & WD & Amazon wood & stem \\
\hline UEA_020 & PT & B. excelsa & seed & UEA_126 & WD & Amazon wood & stem \\
\hline UEA_021 & PT & B. excelsa & seed & UEA_127 & WD & Amazon wood & stem \\
\hline UEA_022 & PT & B. gasipaes & fruit & UEA_128 & WD & Amazon wood & stem \\
\hline UEA_023 & PT & T. cacao & fruit & UEA_129 & WD & Amazon wood & stem \\
\hline UEA_024 & PT & T. cacao & fruit & UEA_130 & WD & Amazon wood & stem \\
\hline UEA_025 & PT & A. vera & leaf & UEA_131 & EP & M. esculenta & stem \\
\hline UEA_026 & PT & T. cacao & fruit & UEA_132 & $\mathrm{EP}$ & M. esculenta & root \\
\hline UEA_027 & PT & B. excelsa & seed & UEA_133 & $\mathrm{EP}$ & M. esculenta & root \\
\hline UEA_028 & PT & A. aculeatum & fruit & UEA_134 & $\mathrm{EP}$ & M. esculenta & stem \\
\hline UEA_029 & PT & B. excelsa & seed & UEA_135 & PT & B. gasipaes & fruit \\
\hline UEA_030 & PT & A. aculeatum & fruit & UEA_136 & PT & A. aculeatum & fruit \\
\hline UEA_031 & PT & B. excelsa & seed & UEA_137 & PT & A. vera & leaf \\
\hline UEA_032 & PT & A. aculeatum & fruit & UEA_138 & PT & T. cacao & fruit \\
\hline UEA_033 & PT & B. gasipaes & fruit & UEA_139 & PT & B. excelsa & seed \\
\hline UEA_034 & PT & B. gasipaes & fruit & UEA_140 & WD & Amazon wood & stem \\
\hline UEA_035 & PT & B. gasipaes & fruit & UEA_141 & WD & Amazon wood & stem \\
\hline UEA_036 & PT & A. aculeatum & fruit & UEA_142 & WD & Amazon wood & stem \\
\hline UEA_037 & PT & B. gasipaes & fruit & UEA_143 & WD & Amazon wood & stem \\
\hline UEA_038 & $\mathrm{EP}$ & M. esculenta & leaf & UEA_144 & WD & Amazon wood & stem \\
\hline UEA_039 & $\mathrm{EP}$ & P. aduncum & leaf & UEA_145 & $\mathrm{EP}$ & P. aduncum & root \\
\hline UEA_040 & $\mathrm{EP}$ & P. aduncum & root & UEA_146 & $\mathrm{EP}$ & P. aduncum & stem \\
\hline UEA_041 & $\mathrm{EP}$ & P. aduncum & leaf & UEA_147 & $\mathrm{EP}$ & P. aduncum & root \\
\hline UEA_042 & $\mathrm{EP}$ & A. aculeatum & seed & UEA_148 & $\mathrm{EP}$ & P. aduncum & root \\
\hline UEA_043 & $\mathrm{EP}$ & P. aduncum & root & UEA_149 & $\mathrm{EP}$ & P. aduncum & leaf \\
\hline UEA_044 & $\mathrm{EP}$ & P. aduncum & stem & UEA_150 & $\mathrm{EP}$ & P. aduncum & leaf \\
\hline UEA_045 & $\mathrm{EP}$ & P. aduncum & root & UEA_151 & $\mathrm{EP}$ & P. aduncum & leaf \\
\hline UEA_046 & $\mathrm{EP}$ & P. aduncum & leaf & UEA_152 & $\mathrm{EP}$ & P. aduncum & leaf \\
\hline UEA_047 & $\mathrm{EP}$ & B. excelsa & leaf & UEA_153 & $\mathrm{EP}$ & P. aduncum & stem \\
\hline UEA_048 & $\mathrm{EP}$ & P. aduncum & root & UEA_154 & $\mathrm{EP}$ & P. aduncum & root \\
\hline UEA_049 & $\mathrm{EP}$ & P. aduncum & root & UEA_155 & $\mathrm{EP}$ & P. aduncum & stem \\
\hline UEA_050 & $\mathrm{EP}$ & B. excelsa & stem & UEA_156 & $\mathrm{EP}$ & P. aduncum & root \\
\hline UEA_051 & $\mathrm{EP}$ & B. excelsa & seed & UEA_157 & $\mathrm{EP}$ & P. aduncum & root \\
\hline UEA_052 & $\mathrm{EP}$ & P. aduncum & stem & UEA_158 & $\mathrm{EP}$ & P. aduncum & root \\
\hline UEA_053 & $\mathrm{EP}$ & A. aculeatum & fruit & UEA_159 & $\mathrm{EP}$ & P. aduncum & root \\
\hline
\end{tabular}


Table 1. continuation

\begin{tabular}{|c|c|c|c|c|c|c|c|}
\hline Strain Code & Type $^{a}$ & Host & Tissue & Strain Code & Type & Host & Tissue \\
\hline UEA_054 & $\mathrm{EP}$ & P. aduncum & stem & UEA_160 & $\mathrm{EP}$ & P. aduncum & leaf \\
\hline UEA_055 & EP & P. aduncum & stem & UEA_161 & $\mathrm{EP}$ & P. aduncum & root \\
\hline UEA_056 & EP & P. aduncum & leaf & UEA_162 & $\mathrm{EP}$ & P. aduncum & stem \\
\hline UEA_057 & EP & P. aduncum & root & UEA_163 & $\mathrm{EP}$ & P. aduncum & stem \\
\hline UEA_058 & EP & P. aduncum & stem & UEA_164 & $\mathrm{EP}$ & P. aduncum & stem \\
\hline UEA_059 & EP & P. aduncum & root & UEA_165 & $\mathrm{EP}$ & P. aduncum & stem \\
\hline UEA_060 & $\mathrm{EP}$ & P. aduncum & root & UEA_166 & $\mathrm{EP}$ & P. aduncum & leaf \\
\hline UEA_061 & $\mathrm{EP}$ & A. aculeatum & seed & UEA_167 & $\mathrm{EP}$ & P. aduncum & root \\
\hline UEA_062 & $\mathrm{EP}$ & P. aduncum & stem & UEA_168 & $\mathrm{EP}$ & P. aduncum & leaf \\
\hline UEA_063 & EP & A. aculeatum & seed & UEA_169 & EP & P. aduncum & leaf \\
\hline UEA_064 & $\mathrm{EP}$ & P. aduncum & root & UEA_200 & WD & Amazon wood & stem \\
\hline UEA_065 & $\mathrm{EP}$ & A. aculeatum & fruit & UEA_201 & WD & Amazon wood & stem \\
\hline UEA_066 & $\mathrm{EP}$ & P. aduncum & leaf & UEA_202 & WD & Amazon wood & stem \\
\hline UEA_067 & $\mathrm{EP}$ & P. aduncum & root & UEA_203 & WD & Amazon wood & stem \\
\hline UEA_068 & $\mathrm{EP}$ & P. aduncum & leaf & UEA_204 & WD & Amazon wood & stem \\
\hline UEA_069 & $\mathrm{EP}$ & P. aduncum & leaf & UEA_205 & WD & Amazon wood & stem \\
\hline UEA_070 & EP & P. aduncum & stem & UEA_206 & WD & Amazon wood & stem \\
\hline UEA_071 & EP & T. cacao & seed & UEA_207 & WD & Amazon wood & stem \\
\hline UEA_072 & EP & A. aculeatum & fruit & UEA_208 & WD & Amazon wood & stem \\
\hline UEA_073 & EP & P. aduncum & root & UEA_209 & WD & Amazon wood & stem \\
\hline UEA_074 & $\mathrm{EP}$ & E. uchi & fruit & UEA_210 & WD & Amazon wood & stem \\
\hline UEA_075 & $\mathrm{EP}$ & P. aduncum & root & UEA_211 & WD & Amazon wood & stem \\
\hline UEA_076 & EP & E. uchi & fruit & UEA_212 & WD & Amazon wood & stem \\
\hline UEA_077 & EP & P. aduncum & leaf & UEA_213 & WD & Amazon wood & stem \\
\hline UEA_078 & EP & P. aduncum & leaf & UEA_214 & WD & Amazon wood & stem \\
\hline UEA_079 & EP & P. aduncum & leaf & UEA_215 & WD & Amazon wood & stem \\
\hline UEA_080 & EP & P. aduncum & leaf & UEA_216 & WD & Amazon wood & stem \\
\hline UEA_081 & $\mathrm{EP}$ & P. aduncum & leaf & UEA_217 & WD & Amazon wood & stem \\
\hline UEA_082 & $\mathrm{EP}$ & P. aduncum & leaf & UEA_218 & WD & Amazon wood & stem \\
\hline UEA_083 & PT & A. vera & leaf & UEA_219 & WD & Amazon wood & stem \\
\hline UEA_084 & PT & Saccharum sp. & fruit & UEA_220 & WD & Amazon wood & stem \\
\hline UEA_085 & PT & Banana & fruit & UEA_221 & WD & Amazon wood & stem \\
\hline UEA_086 & PT & Banana & fruit & UEA_222 & WD & Amazon wood & stem \\
\hline UEA_087 & PT & T. cacao & fruit & UEA_223 & WD & Amazon wood & stem \\
\hline UEA_088 & PT & T. cacao & fruit & UEA_224 & WD & Amazon wood & stem \\
\hline UEA_089 & WD & Amazon wood & stem & UEA_225 & WD & Amazon wood & stem \\
\hline UEA_090 & WD & Amazon wood & stem & UEA_226 & WD & Amazon wood & stem \\
\hline UEA_091 & WD & Amazon wood & stem & UEA_227 & WD & Amazon wood & stem \\
\hline UEA_092 & WD & Amazon wood & stem & UEA_228 & WD & Amazon wood & stem \\
\hline UEA_093 & WD & Amazon wood & stem & UEA_229 & WD & Amazon wood & stem \\
\hline UEA_094 & WD & Amazon wood & stem & UEA_230 & WD & Amazon wood & stem \\
\hline UEA_095 & WD & Amazon wood & stem & UEA_231 & WD & Amazon wood & stem \\
\hline UEA_096 & WD & Amazon wood & stem & UEA_232 & WD & Amazon wood & stem \\
\hline UEA_097 & WD & Amazon wood & stem & UEA_233 & WD & Amazon wood & stem \\
\hline UEA_098 & WD & Amazon wood & stem & UEA_234 & WD & Amazon wood & stem \\
\hline UEA_099 & WD & Amazon wood & stem & UEA_235 & WD & Amazon wood & stem \\
\hline UEA_100 & WD & Amazon wood & stem & UEA_236 & WD & Amazon wood & stem \\
\hline UEA_101 & WD & Amazon wood & stem & UEA_237 & WD & Amazon wood & stem \\
\hline UEA_102 & WD & Amazon wood & stem & UEA_238 & WD & Amazon wood & stem \\
\hline UEA_103 & WD & Amazon wood & stem & UEA_239 & WD & Amazon wood & stem \\
\hline UEA_104 & WD & Amazon wood & stem & UEA_240 & WD & Amazon wood & stem \\
\hline UEA_105 & WD & Amazon wood & stem & UEA_241 & WD & Amazon wood & stem \\
\hline UEA_106 & $\mathrm{EP}$ & M. esculenta & leaf & UEA_242 & WD & Amazon wood & stem \\
\hline
\end{tabular}

${ }^{\mathrm{a}} \mathrm{EP}=$ Endophytic; $\mathrm{PT}$ = Phytopathogenic; $\mathrm{WD}=$ Wood-degrading. 
of tributyrine in the initial selection of microorganisms with lipolytic enzymes, but with later confirmation with other lipid substrates of greater specificity for lipases. ${ }^{33}$

Recent studies have adopted as a criterion the size of the acyl chain resulting from the hydrolysis of acylglycerol to distinguish between lipases and esterases. ${ }^{48}$ Lipases (EC 3.1.1.3) have been characterized as carboxylesterases which hydrolyze long chain acylglycerides (with more than 10 carbon atoms) and the enzymes which hydrolyze acylglycerides with a chain size of less than 10 carbon atoms are considered esterases (EC 3.1.1.1). ${ }^{49}$ Esterases and lipases differ in the size of this hydrophobic interaction area as well as in the shape, deepness and physico-chemical properties of their substrate binding pocket. ${ }^{50}$ However, according to Faber, the main difference between lipases and esterases is their physico-chemical interaction with their substrates, since these enzymes have distinct kinetic behaviors. ${ }^{4}$

Most lipases show activity at the interface of an aqueous and non-aqueous solvent, known as interfacial enzyme activation, the activity of which is associated with conformational changes in the protein domain called 'lid', which gives the substrate access to the active site. $.8,51$ However, some lipases have little or no interfacial activation and, thus, show both the activities of lipases and esterases. ${ }^{52}$ Consequently, hydrolysis catalyzed by lipases must be preferentially carried out in biphasic medium, the use of a substrate in a concentration which constitutes an organic phase in an aqueous medium or solubilization of the substrate in a hydrophobic solvent $(\log \mathrm{P}>1.5)$ being sufficient. ${ }^{4}$

In order to verify the hydrolytic capacity of the lipases produced by Amazonian fungi, the test was carried out in the presence of olive oil, a substrate considered more specific for lipases than tributyrine, ${ }^{33}$ since olive oil is composed of $71 \%$ oleic acid. ${ }^{53}$ The test with olive oil was applied to 22 fungi which tested positive in the tributyrine assay, selected randomly.

Of the 22 isolates evaluated, seven fungi (UEA_006, UEA_041, UEA_053, UEA_055, UEA_057, UEA_064 and UEA_015) gave a negative result in the test with olive oil, suggesting that the positive results in the test with tributyrine of these strains was due to the action of esterases.

The 185 Amazon fungi which showed the formation of halos in the tests with tributyrine were cultivated in a lipase production inductor liquid medium. The fungi which showed good growth were then selected for the synthetic screening.

\section{Synthetic screening}

The 64 isolates which had the best growth in the lipase production inductor medium, reaching greater mycelium masses after nine days of cultivation, were selected to carry out the biocatalytic reactions for synthetic screening using hexane as the solvent.

Considering that lipases are employed in both hydrolytic and synthetic reactions, good results in hydrolytic reactions do not guarantee good performances in synthetic reactions in organic solvents. Thus, synthetic screening is fundamental to evaluate the potential application of mycelium-bound lipases. ${ }^{23,29}$ Purified commercial enzymes, although widely available, are not selected specifically for catalytic reactions in non-aqueous environments. Thus, synthetic screening in organic media is an alterative which allows the selection of enzymes with specific characteristics for the reaction of interest. ${ }^{54}$

The results of the synthetic screening are shown in Figures 2, 3 and 4, which give only the results of the reactions mediated by the Amazonian fungi with a conversion above $10 \%$.

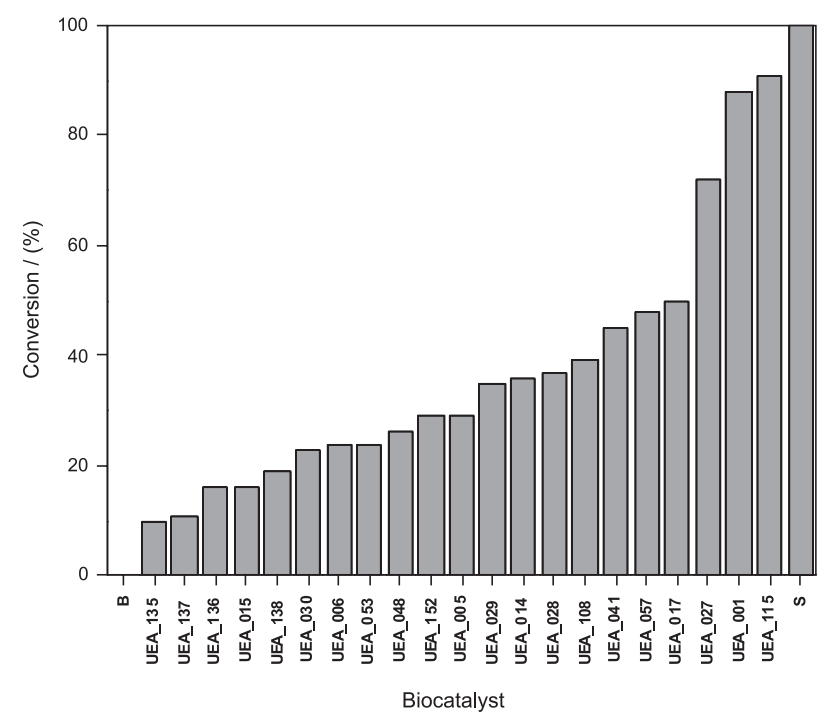

Figure 2. Conversions to pentyl oleate in biocatalytic reactions mediated by Amazonian fungi at $28{ }^{\circ} \mathrm{C}$ and $72 \mathrm{~h}$. B and S stand for blank and standard control reactions, respectively.

In the synthesis of pentyl oleate, 21 fungi showed conversions above $10 \%$, with four being above $50 \%$. The isolates UEA_115, UEA_001 and UEA_027 had the most notable performance with $91 \%, 88 \%$ and $72 \%$ conversion, respectively (Figure 2). In the synthesis of dodecyl linoleate, 15 fungi had conversions above $10 \%$ with six above 50\%. The isolates UEA_007, UEA_115 and UEA_041 were the most efficient in this reaction with $98 \%, 94 \%$ and $78 \%$ conversion, respectively (Figure 3 ). In the synthesis of ethyl palmitate, 14 fungi had conversions above $10 \%$ with five above $50 \%$. The fungi UEA_007 and UEA_001 had the best results in this reaction, with $87 \%$ and $79 \%$ of conversion, respectively (Figure 4). It can be 


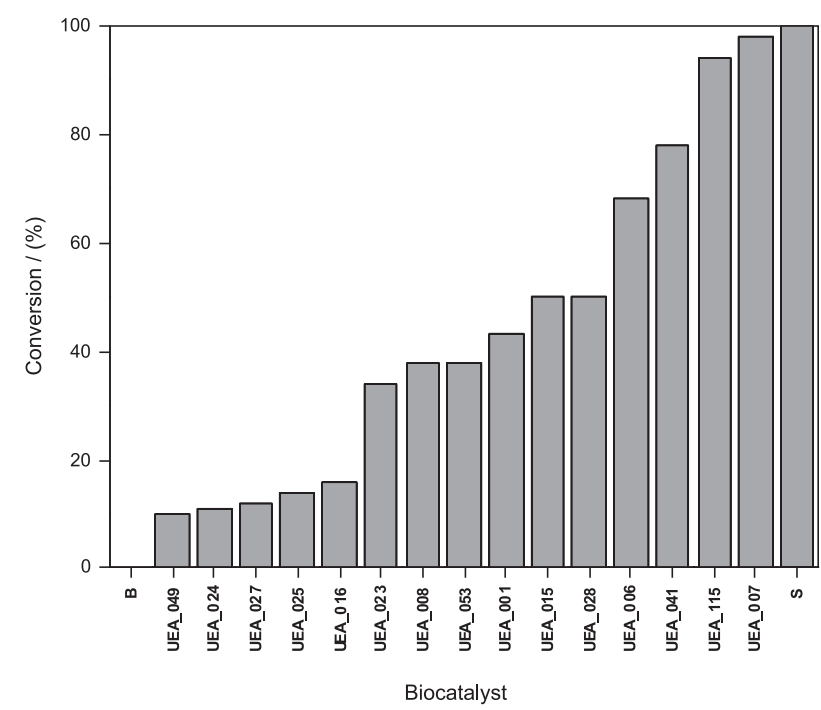

Figure 3. Conversions to dodecyl linoleate in biocatalytic reactions mediated by Amazonian fungi at $28^{\circ} \mathrm{C}$ and $72 \mathrm{~h}$. B and S stand for blank and standard control reactions, respectively.

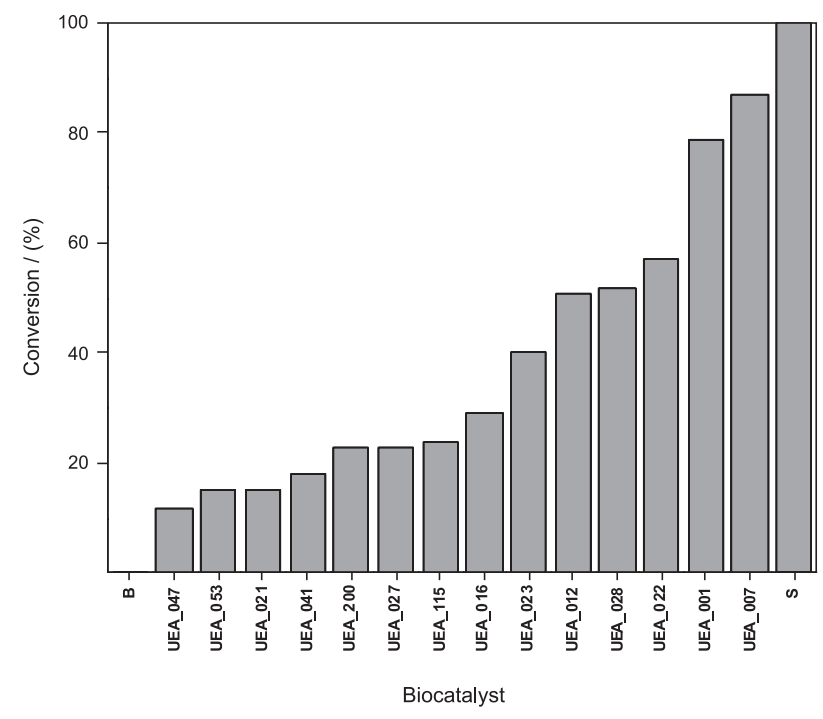

Figure 4. Conversions to ethyl palmitate in biocatalytic reactions mediated by Amazonian fungi at $28^{\circ} \mathrm{C}$ and $72 \mathrm{~h}$. B and S stand for blank and standard control reactions, respectively.

seen from these results that the Amazonian fungi evaluated produced lipases with pronounced synthetic activity, being able to act efficiently on the substrates used.

Some strains had a good biocatalytic activity for more than one type of substrate. The strain UEA_001, for example, obtained $88 \%$ of conversion to pentyl oleate and $79 \%$ of conversion to ethyl palmitate. This behavior was similar to that observed for the fungus UEA_ 007 which showed $98 \%$ of conversion to dodecyl linoleate and $87 \%$ of conversion to ethyl palmitate. These two isolates had excellent performance for both the esterification and transesterification reactions, obtaining conversion percentages comparable with the commercial enzyme
Novozym 435 (100\% conversion). These results suggest two possibilities: the fungi UEA_001 and UEA_007 have mycelium-bound lipases able to promote excellent conversions to the product, acting on substrates with different chemical structures; or these strains produce different lipases, specific to each of the two substrates.

Using the isolate UEA_115 excellent conversions to product were observed in the two esterification reactions evaluated. This strain showed $91 \%$ conversion to pentyl oleate and $94 \%$ conversion to dodecyl linoleate. In this case, a preference of the lipases produced by this fungus for the esterification reaction was noted, since in the transesterification reaction the conversion to ethyl palmitate was $24 \%$. The small structural differences in the substrates studied appear not to limit the action of myceliumbound lipases produced by this isolate in esterification reactions.

It is known that lipases can convert a large variety of nonnatural substrates, indicating that they are not completely 'rigid' enzymes, but undergo small conformational changes during the formation of the enzyme-substrate complex. This characteristic gives lipases a great versatility for the catalysis of different reactions. Furthermore, the 'induced fit' mechanism developed by Koshland at the end of the $1960 \mathrm{~s}^{55}$ indicated that the enzyme can change its conformation under the influence of the substrate structure, and according to Faber, "The most typical induced-fit enzymes are the lipases". ${ }^{4}$

On the other hand, reactions carried out in organic solvents, in general, result in enzymes with greater rigidity, since in aqueous medium the breaking and formation of hydrogen bonds involved in the formation of the enzymesubstrate complex are assisted by water, which does not occur in hydrophobic solvents. ${ }^{56}$ Another factor that may influence the selectivity of biocatalysts is immobilization. ${ }^{4}$ Nascimento et al. ${ }^{57}$ reported that the use of immobilized lipase increased the enantioselectivity and the conversion percentage in the resolution of $\alpha$-methylene- $\beta$-hydroxy esters, when compared to the reaction with the free enzyme.

In the enzymes adhered to the mycelium, the structure formed by the mass of hyphae acts as a natural matrix and produces an effect similar to that of supports used in the immobilization of biocatalysts, ${ }^{27}$ that is, the myceliumbound lipases may have a less flexible three-dimensional conformation, and thus only more specific substrates will be transformed.

The mycelium-bound lipases of the isolates UEA_027 and UEA_041 showed less flexibility in relation to the different substrates used in the synthetic screening reactions, since in contrast to the isolates UEA_001, 
UEA_007 and UEA_115, only one of the substrates was successfully biotransformed. With the isolate UEA_027 a good percentage of conversion to pentyl oleate $(72 \%)$ was obtained, with the isolate UEA_041 showing 78\% conversion to dodecyl linoleate. These two isolates did not show good performances in the other biocatalytic reactions (conversions below 45\%) under the experimental conditions employed. However, they were able to use the substrates, suggesting that, after optimization of the reaction conditions, the performance of these enzymes can be improved.

In order to select the fungi with the best performance for biocatalysis application, a comparison between the results obtained in the hydrolysis and synthesis reactions was considered (Table 2).

Hydrolytic activity screening methods in solid medium can be easily carried out for large numbers of organisms, but they are not suitable to evaluate the true potential for the production of enzymes of synthetic interest. ${ }^{26}$ The differences between the levels of synthetic and hydrolytic activity may be accentuated by the fact that tests such as that with tributyrine analyze the activity of both extracellular and myceliumbound hydrolases in hydrophilic medium, whereas the synthesis of esters indicates the presence of mycelium-bound lipase activity in hydrophobic medium. ${ }^{23,26}$

The isolates UEA_001,UEA_007, UEA_028, UEA_041 and UEA_115, gave positive results in the hydrolytic tests and presented at least one high conversion percentage (> 52\%) in one of the synthetic reactions (Table 2).
These isolates can be considered the most versatile within those studied and, consequently, the most promising to be employed in biocatalysis.

The isolates UEA_006, UEA_012, UEA_015, UEA_016, UEA_018, UEA_041 and UEA_053 showed positive results in the hydrolytic test with the tributyrine substrate and negative results in the test with olive oil. Although these strains did not hydrolyze this substrate, many showed significant synthetic activity (Table 2). Thus, the results suggest that the hydrolytic test with the substrate olive oil, for these experimental conditions, is not a suitable method for the screening of lipases with application in organic synthesis, since these seven fungi would be eliminated during the hydrolytic selection. Therefore, these results confirm the data in the literature, ${ }^{23,29}$ which state that there is no correlation between the hydrolytic and synthetic activity of lipases.

One of the main applications of lipases in biocatalysis is the obtainment of enantiomerically pure compounds. ${ }^{20}$ Therefore, after the screening tests, nine strains of fungi (Aspergillus and Trichoderma genus) isolated from Amazon region plants were selected (UEA_001, UEA_006, UEA_007, UEA_014, UEA_023, UEA_027, UEA_041, UEA_053 and UEA_115). These had the highest conversion percentages in synthetic activity screening. These nine fungi are being identified through molecular biology techniques. For the preliminary evaluation of the enantioselective potential of the nine strains selected, the resolution of $(R, S)$-2-octanol reaction was carried out.

Table 2. Performance of the Amazonian fungi in the different screening tests

\begin{tabular}{|c|c|c|c|c|c|}
\hline Isolate & Tributyrine $^{a}$ & Olive oil $^{\mathrm{a}}$ & Pentyl oleate $/(\%)$ & Dodecil linoleate $/(\%)$ & Ethyl palmitate $/(\%)$ \\
\hline UEA_027 & + & + & 72 & 12 & 23 \\
\hline UEA_001 & + & + & 88 & 43 & 79 \\
\hline UEA_017 & + & + & 50 & 1 & 5 \\
\hline UEA_115 & + & + & 91 & 94 & 24 \\
\hline UEA_041 & + & - & 45 & 78 & 18 \\
\hline UEA_053 & + & - & 24 & 38 & 15 \\
\hline UEA_016 & + & - & 2 & 16 & 29 \\
\hline UEA_028 & + & + & 37 & 50 & 52 \\
\hline UEA_023 & + & + & 6 & 34 & 40 \\
\hline UEA_006 & + & - & 24 & 68 & 0 \\
\hline UEA_007 & + & + & 8 & 98 & 87 \\
\hline UEA_012 & + & - & 1 & 8 & 51 \\
\hline UEA_015 & + & - & 16 & 50 & 4 \\
\hline UEA_018 & + & - & 0 & 0 & 18 \\
\hline
\end{tabular}

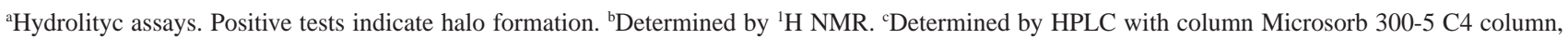
acetonitrile/water gradient. 


\section{Resolution of $(R, S)$-2-octanol}

Lipases have been widely applied as versatile biocatalysts for the kinetic resolution of various racemates. ${ }^{16,17,55-57}$ Our research group has initiated the screening of enantioselective lipase from Amazonian fungi with the resolution of $(R, S)$ 2-hexanol. A good potential of these microorganisms for producing chiral compounds was observed. ${ }^{58}$ Thus, following these studies on enantioselective screening, the isolates selected in the synthetic reactions were used to mediate the resolution of the $(R, S)$-2-octanol reaction via transesterification with vinyl acetate (acyl donor). The values for the conversion percentages (\%c), substrate and product enantiomeric excess $\left(e e_{\mathrm{s}}\right.$ and $\left.e e_{\mathrm{p}}\right)$, and enantiomeric ratio (E) can be seen in Table 3 .

Table 3. Conversion and enantioselectivity of the $(R, S)$-2-octanol resolution reaction mediated by Amazonian fungi after $120 \mathrm{~h}$ reaction

\begin{tabular}{lcccc}
\hline Biocatalyst & $\begin{array}{c}\text { Percentage } \\
\text { Conversion }\end{array}$ & $\% e e_{\mathrm{s}}^{\mathrm{b}}$ & $\% e e_{\mathrm{p}}^{\mathrm{b}}$ & $\mathrm{E}^{\mathrm{d}}$ \\
\hline UEA_001 & 0 & 0 & 0 & 0 \\
UEA_006 & 5 & 6 & 99 & $>200$ \\
UEA_007 & 8 & 9 & 99 & $>200$ \\
UEA_014 & 5 & 6 & 99 & $>200$ \\
UEA_023 & 2 & 3 & 99 & $>200$ \\
UEA_027 & 7 & 8 & 99 & $>200$ \\
UEA_041 & 8 & 9 & 99 & $>200$ \\
UEA_053 & 18 & 22 & 99 & $>200$ \\
UEA_115 & 22 & 29 & 99 & $>200$ \\
Nov0zym 435 & 69 & 99 & 44 & 11 \\
\hline
\end{tabular}

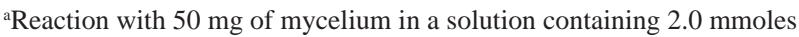
of (R,S)-2-octanol and 6.0 mmoles of vinyl acetate in $10 \mathrm{~mL}$ of $n$-hexane. ${ }^{b}$ Determined by GC-MS with Chirasil-Dex CB column. ${ }^{\mathrm{d}}$ Calculated according to the formula described by Faber (2004).

The values for the parameters used to evaluate the enantioselective activity given in Table 3 show that the fungal strains displayed a resolution capacity lower than Novozym 435, since the biocatalytic reactions mediated by Amazonian fungi presented lower $e e_{\mathrm{s}}$ than the commercial enzyme.

According to Faber, E values lower than 15 are unacceptable for practical purposes. $\mathrm{E}$ values between 15 and 30 are considered moderate to good, and above these values are excellent, a value of 200 being the limit of accuracy of the technique, since, above this value, even an extremely small variation in $e e_{\mathrm{s}}$ or $e e_{\mathrm{p}}$ causes a significant change in the numerical value of E. ${ }^{4}$

The reactions mediated by the Amazonian fungi gave values for the conversion of methyl heptyl acetate lower than the reaction using Novozym 435 . However, two fungal isolates (UEA_053 and UEA_115) showed promising enantioselective capacity, since they had high values of $e e_{\mathrm{p}}$ and E. The strain UEA_053 presented $e e_{\mathrm{s}} 22 \% ; e e_{\mathrm{p}} 99 \%$; $18 \%$ and $\mathrm{E}>200$, whereas the isolate UEA_115 showed $e e$ s $29 \%$; $e e_{\mathrm{p}} 99 \%$; c $22 \%$ and $\mathrm{E}>200$. These results indicate the potential of these two strains for the obtainment of optically active alcohols. Consequently, the optimization of the reaction conditions will be of fundamental importance to increase conversion to the product.

\section{Conclusions}

The fungi isolated from plants of the Amazon region showed a great potential as providers of mycelium-bound lipases for use in biotransformations. Of the 212 fungi evaluated in this study, the mycelium-bound lipases of the isolates UEA_001, UEA_007 and UEA_115 showed properties desirable for use in biocatalysis: good hydrolysis activity, and good esterification and transesterification capacity in organic media. The isolate UEA_115 was the most versatile biocatalyst, since it presented good performance in the esterification reactions (conversions $>90 \%$ ) and also showed potential for resolution of racemic 2-octanol (ee $29 \%$; ee $99 \%$; c 22\%; E > 200).

These results confirm the difficultly in obtaining a universal method for the selection of microorganisms which produce lipases, since for each specific substrate and type of reaction employed a suitable biocatalysts can be found from the biodiversity available.

On comparing the action of the Amazonian fungi selected with the commercial enzyme Novozym 435, it can be observed that the non-purified mycelium-bound lipases showed excellent biocatalytic potential. It is important to note that most of the enzymes used in organic synthesis are employed in the form of a crude extract, with low cost. However, the preparations contain only around 1 to $30 \%$ of the enzyme of interest, the rest being inactive proteins, stabilizers, buffers or carbohydrates originating from the culture broth from which they were obtained. ${ }^{4}$ Also, it should be considered that crude preparations are frequently more stable than purified enzymes, since they constitute more robust catalytic systems, as can be observed in the results obtained in this study.

The studies in the area of biocatalysis have contributed to strengthening the relationship between chemistry and biotechnology, employing knowledge of chemistry in biological sciences, and encouraging scientists from both fields of knowledge to work in collaboration. ${ }^{62}$ Furthermore, biocatalytic screening is a tool which effectively contributes to knowledge of the biodiversity of the Amazon region, 
since the species still not accessed may provide products of great utility to mankind, which represents a key argument in favor of its conservation. ${ }^{63}$

\section{Acknowledgments}

The authors would like to thank CAPES, CNPq and FAPEAM for financial support; Dr. Massayoshi Yoshida, Luis Carlos Roque, and Raimundo Carlos Pereira Junior (CBA) for the ${ }^{1} \mathrm{H}$ NMR and GC-MS analysis; Dr. Maria da Graça Nascimento (UFSC) for providing reagents and other contributions; Dr. Ademir Castro e Silva (UEA) for kindly providing the fungi; Dr. José Odair Pereira (UFAM) for the use of his laboratory during the initial phases of this study and Dr. Antônia Queiroz Lima de Souza (UEA) for her collaboration in the identification and storage of the fungi.

\section{Supplementary Information}

Chromatograms used for the determination of conversion, enantiomeric excess and enantiomeric ratio of $(R, S)$-2-octanol resolution reactions are available free of charge at http://jbcs.sbq.org.br, as PDF file.

\section{References}

1. OECD; The Application of Biotechnology to Industrial Sustainability, OECD Publications Service: Paris, 2001.

2. Buchholz, K.; Kasche, V.; Bornscheuer, U. T.; Biocatalysis and Enzyme Technology, $1^{\text {st }}$ ed., Wiley-VCH Verlag Gmbh \& Co.KgaA: Weinheim, 2005.

3. Bommarius, A. S.; Riebel, B. R; Biocatalysis, Wiley-VCH Verlag Gmbh \& Co.KgaA: Weinheim, 2004.

4. Faber, K.; Biotransformations in Organic Chemistry, $5^{\text {th }}$ ed., Springer-Verlag: Berlim, 2004.

5. Silva, F. M.; Lacerda, P. S. B.; Jones Jr., J.; Quim. Nova 2005, $28,103$.

6. Schmid, A.; Dordick, S. J.; Hauer, B.; Kieners, A.; Wubbolts, M.; Witholt, B.; Nature 2001, 409, 258.

7. Van Belien, J. B.; Li, Z.; Curr. Opin. Biotechnol. 2002, 13, 338.

8. Pinheiro, S.; Ferreira, V. F.; Quim. Nova 1998, 21, 312.

9. Gotor-Fernandez, V.; Brieva, R.; Gotor, V.; J. Mol. Catal. B: Enzym. 2006, 40, 111.

10. Ogawa, J.; Shimizu, S.; Curr. Opin. Biotechnol. 2002, 13, 367.

11. Sahoo, S.; Kumar, P.; Lefebvre, F.; Halligudi, F. B.; Appl. Catal., A 2009, 354, 17.

12. Wang, P.-Y.; Tsai, S.-W.; J. Mol. Catal. B: Enzym. 2009, 59, 70.

13. Jurcek, O.; Wimmerova, M.; Zdenek,W.; Coord. Chem. Rev. 2008, 252, 767.
14. Fessner, W. D.; Adv. Synth. Catal. 2003, 345, 32.

15. Gomes, F. M.; Paula, A. V.; Silva, G. S.; Castro, H. F.; Quim. Nova 2006, 29,710.

16. Carvalho, P. O.; Calafatti, S. A.; Marassi, M.; Silva, D. M.; Contesini, F. J.; Bizaco, R.; Quim. Nova 2005, 28, 614.

17. Carvalho, P. O.; Cass, Q. B.; Calafatti, S. A.; Contesini, F. J.; Bizaco, R.; Braz. J. Chem. Eng. 2006, 23, 291.

18. Jaeger, K. E.; Eggert, T.; Curr. Opin. Biotechnol. 2002, 13, 390.

19. Hasan, F.; Alishah, A.; Hameed, A.; Enzyme Microb. Technol. 2006, 39, 235.

20. Ghanem, A.; Tetrahedron 2007, 63, 1721.

21. Jaeger, K. E.; Reetz, M. T.; Tibtech 1998, 16, 396.

22. Castro, H. F.; Mendes, A. A.; Santos, J. C.; Aguiar, C. L.; Quim. Nova 2004, 27, 146.

23. Torres, M.; Dolcet, M. M.; Sala, N.; Canela, R.; J. Agric. Food Chem. 2003, 51, 3328.

24. Dalla-Vechia, R.; Nascimento, M. G.; Soldi, V.; Quim. Nova 2004, 27, 623 .

25. Torres, M.; Barbosa, E.; Loscos, V.; Canela, R.; Biotechnol. Lett. 2000, 22, 1265.

26. Gandolfi, R.; Marinelli, F.; Lazzarini, A.; Molinari, F.; J. Appl. Microbiol. 2000, 89, 870.

27. Romero, M. C.; Baigori, M. D.; Pera, M. L.; Appl. Microbiol. Biotechnol. 2007, 69, 1067.

28. Souza, A. Q. L.; Souza, A. D. L.; Astolffi Filho, S.; Belém Pinheiro, M. L.; Sarquis, M. I. M.; Pereira, J. O.; Acta Amaz. 2004, 34, 185.

29. Cardenas, F.; Alvarez, E.; Castro-Alvarez, M. S.; SanchezMontero, J. M.; Valmaseda, M.; Elson, S. W.; Sinisterra, J. V.; J. Mol. Catal. B: Enzym. 2001, 14, 111.

30. Araújo, W. L.; Lima, A. O. S.; Azevedo, J. L.; Marcon, J.; Sobral, J. K.; Lacava, P. T.; Manual: Isolamento de Microrganismos Endofíticos; CALQ: Piracicaba, Brazil, 2002.

31. Dhingra, O. D.; Sinclair, J. B.; Basic Plant Pathology Methods, CRC Press: Boca Raton, 1995.

32. Lawrence, R. C.; Fryer, T. F.; Reiter, B.; Nature 1967, 213, 1264.

33. Colen, G.; PhD Thesis, Universidade Federal de Minas Gerais, Brazil, 2006

34. Sebrão, D.; Silva, V. D.; Nascimento, M. G.; Moreira, M. A.; Quim. Nova 2007, 30, 1182.

35. Duvoisin Jr., S.; Albuquerque, P. M.; Lima, F. A.; Pinheiro, L. M.; Zanotto, S. P.; Castro e Silva, A.; Abstracts of the IV Workshop de Biocatálise e Biotransformação, São Carlos, Brazil, 2008.

36. Azevedo, J. L.; Maccheroni Jr., W.; Pereira, J. O.; Araújo, W. L.; Electronic J. Biotechnol. 2000, 3, 15; available at http://www. ejb.org/content/vol3/isse1/full/3/4, acessed in january 2009.

37. Carrim, A. J. I.; Barbosa, E. C.; Vieira, J. D. G.; Braz. Arch. Biol. Technol. 2006, 49, 353. 
38. Araújo, J. M.; Silva, A. C.; Azevedo, J. L.; Braz. Arch. Biol. Technol. 2000, 43, 447.

39. Strobel, G. A.; Crit. Rev. Biotechnol. 2002, 22, 315.

40. Stierle, A.; Strobel, G. and Stierle, D.; Science 1993, 260, 214.

41. Clement, C. R.; Aguiar, J. P. L.; Arkcoll, D. B.; Revista Bras. Fruticultura 1998, 20, 115.

42. Ionita, A.; Moscovici, M.; Popa, C.; Vamanu, A.; Popa, O.; Dinu, L.; J. Mol. Catal. B: Enzym. 1997, 3, 147.

43. Colen, G.; Junqueira, G. R.; Moraes-Santos, T.; World J. Microbiol. Biotechnol. 2006, 22, 881.

44. Sztajer, H.; Maliszewska, I.; Wieczorek J.; Enzyme Microb. Technol. 1988, 10, 492.

45. Chunhieng, T.; Hafidi, A.; Pioch, D.; Brochier, J.; Montet, D.; J. Braz. Chem. Soc. 2008, 19, 1374.

46. Costas, M.; Deive, F. J.; Longo, M. A.; Process Biochem. 2004, 39, 2109.

47. Jensen, R. G.; Lipids 1983, 18, 650.

48. Tirawongsaroj, P.; Sriprang, R.; Harnpicharnchai, P.; Thongaram, T.; Champreda, V.; Tanapongpipat, S.; Pootanakit, K.; Eurwilaichitr, L.; J. Biotechnol. 2008, 133, 42.

49. Lima, G. M. V.; PhD Thesis, Universidade Federal do Paraná, Brazil, 2004

50. Pleiss J.; Fischer, M.; Schmid, R. D.; Chem. Phys. Lipids 1998, 93, 67.

51. Cygler, M.; Schrag, J. D.; Biochim. Biophys. Acta 1999, 1441, 205.
52. Verger, R.; Trends Biotechnol. 1997, 15, 32.

53. Wang, D.; Xu, Y.; Shan, T.; Biochem. Eng. J. 2008, 41, 30.

54. Torres, S.; Castro, G. R.; Food Technol. Biotechnol. 2004, 42, 271.

55. Koshland, D. E.; Neet, K. E.; Annu. Rev. Biochem. 1968, 37, 359

56. Broos, J.; Visser A. J. W. G.; Engbersen J. F. J.; Van Hoek A.; Reinhoudt, D. N.; J. Am. Chem. Soc. 1995, 117, 12657.

57. Nascimento, M. G.; Zanotto, S. P.; Melegari, S. P.; Fernandes, L.; Sá, M. M.; Tetrahedron: Asymmetry 2003, 14, 3111.

58. Ng, I.-S.; Tsai, S.-W.; Biotechnol. Bioeng. 2005, 91, 106.

59. Ema, T.; Curr. Org. Chem. 2004, 8, 1009.

60. Kazlauskas, R. J.; Bornscheuer, U. T. In Biotecnology; Rehm, H.-J.; Reed, G., eds., Wiley-VCH: Weinheim, 1998, ch. 3.

61. Lisbôa, L. U. S.; MSc Thesis, Universidade do Estado do Amazonas, Brazil, 2006.

62. Leuerberger, H. G. W.; Pure Appl. Chem. 1990, 62, 753.

63. Smith, S. A.; Tank, D. C.; Boulanger, L.-A.; Bascom-Slack, C. A.; Eisenman, K.; Kingery, D.; Babbs, B.; Fenn, K.; Greene, J. S.; Hann, B. D.; Keehner, J.; Kelley-Swift, E. G.; Kembaiyan, V.; Lee, S. J.; Li, P.; Light, D. Y.; Lin, E. H.; Ma, C.; Moore, M.; Schorn, M. A.; Vekhter, D.; Nunez, P. V.; Strobel, G. A.; Donoghue, M. J.; Strobel; S. A.; PLoS ONE 2008, 3, 1.

Received: January 31, 2009 Web Release Date: June 12, 2009 


\section{Potential Application in Biocatalysis of Mycelium-Bound Lipases from Amazonian Fungi}

\section{Sandra P. Zanotto, ${ }^{*, a}$ Israel P. Romano, ${ }^{a}$ Líliam U. S. Lisboa, ${ }^{a}$ Sergio Duvoisin Jr., ${ }^{a}$ Mayra K. Martins, ${ }^{b}$ Fabiana A. Lima, ${ }^{a}$ Soraya F. Silva ${ }^{a}$ and Patrícia M. Albuquerque ${ }^{a}$}

${ }^{a}$ Laboratório de Biorgânica, Programa de Pós-graduação em Biotecnologia e Recursos Naturais da Amazônia, Universidade do Estado do Amazonas, 69050-030 Manaus-AM, Brazil

${ }^{b}$ Centro de Biotecnologia do Amazonas, 69075-351 Manaus-AM, Brazil

Chromatograms used for the determination of conversion, enantiomeric excess and enantiomeric ratio of $(R, S)$-2-octanol resolution reactions are presented. Analyses were performed by gas chromatography coupled to mass spectrometry (Shimadzu GCMS-QP2010) using a chiral stationary phase (Chirasil-Dex CB $25 \mathrm{~m} \times 0.25 \mathrm{~mm}$ ID $\times$ $0.25 \mathrm{~mm}$ ). Column temperature was $80^{\circ} \mathrm{C}$. The He pressure was $56.9 \mathrm{kPa}$ and the temperatures of the injector and the detector were $220^{\circ} \mathrm{C}$ and $275^{\circ} \mathrm{C}$, respectively.

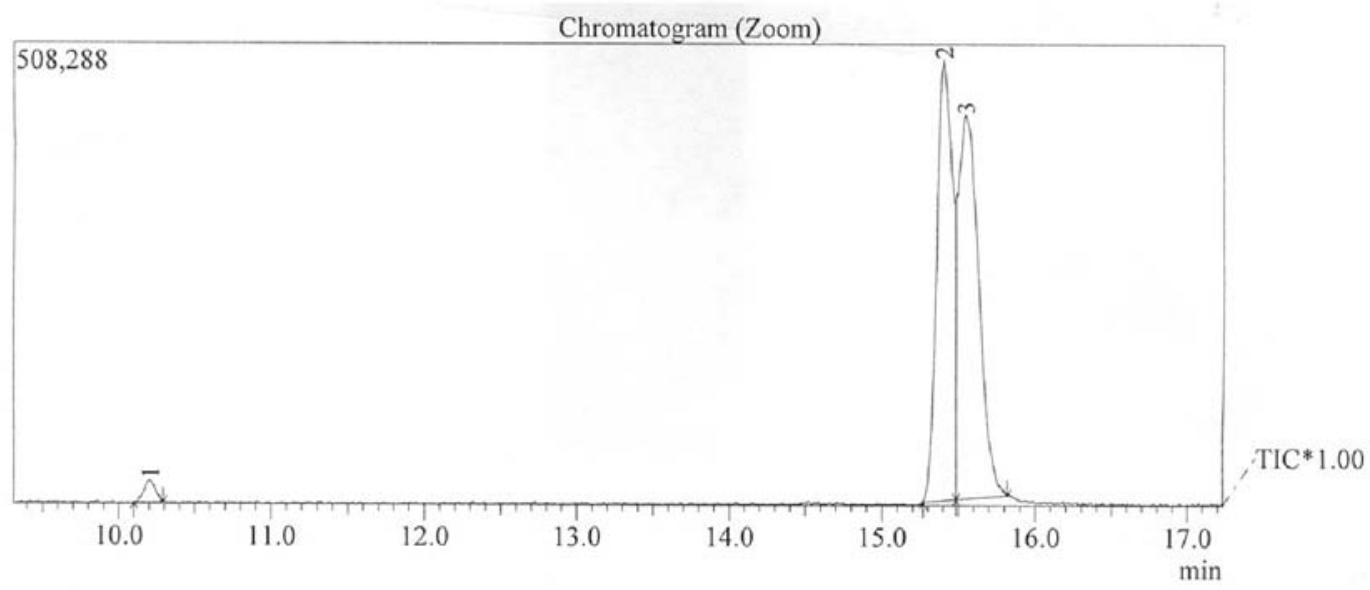

Peak \# 1: Reaction By-product

Peak \# 2: $(R)$ or $(S)$-2-octanol

Peak \# 3: $(R)$ or $(S)$-2-octanol

Figure S1. GC-MS chromatogram of $(R, S)$-2-octanol resolution mediated by the isolate UEA_001. 


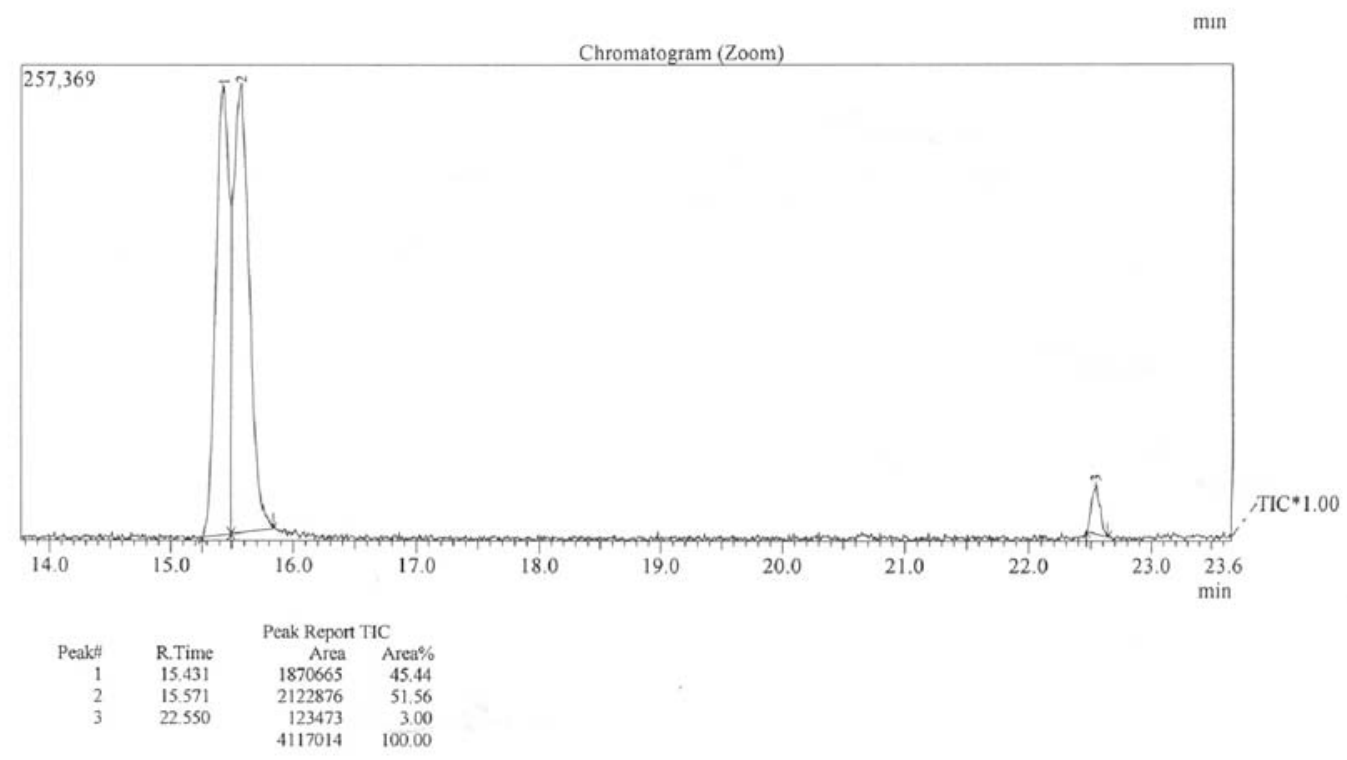

Peak \# 1: $(R)$ or $(S)$-2-octanol

Peak \# 2: $(R)$ or $(S)$-2-octanol

Peak \# 3: $(R)$ or $(S)$-1-methylheptil acetate

Figure S2. GC-MS chromatogram of $(R, S)$-2-octanol resolution mediated by the isolate UEA_006.

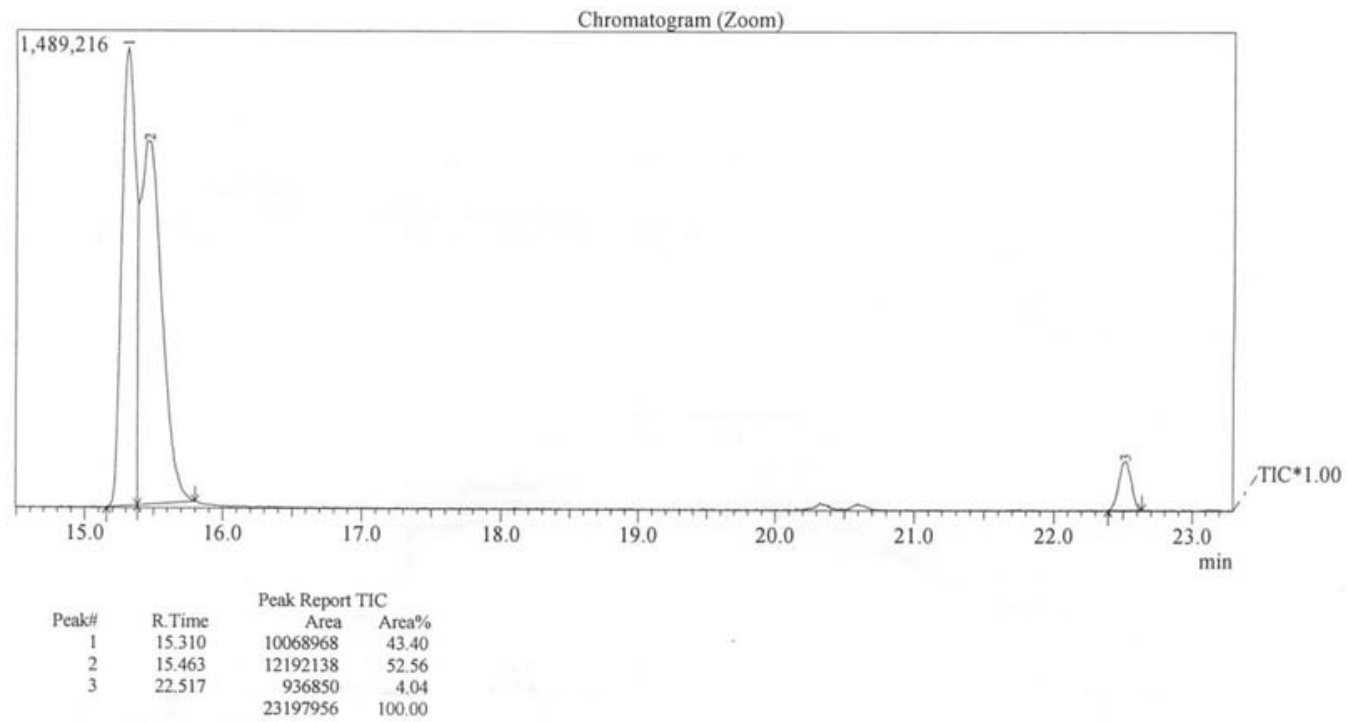

Peak \# 1: $(R)$ or $(S)$-2-octanol

Peak \# 2: $(R)$ or $(S)$-2-octanol

Peak \# 3: $(R)$ or $(S)$-1-methylheptil acetate

Figure S3. GC-MS chromatogram of $(R, S)$-2-octanol resolution mediated by the isolate UEA_007. 


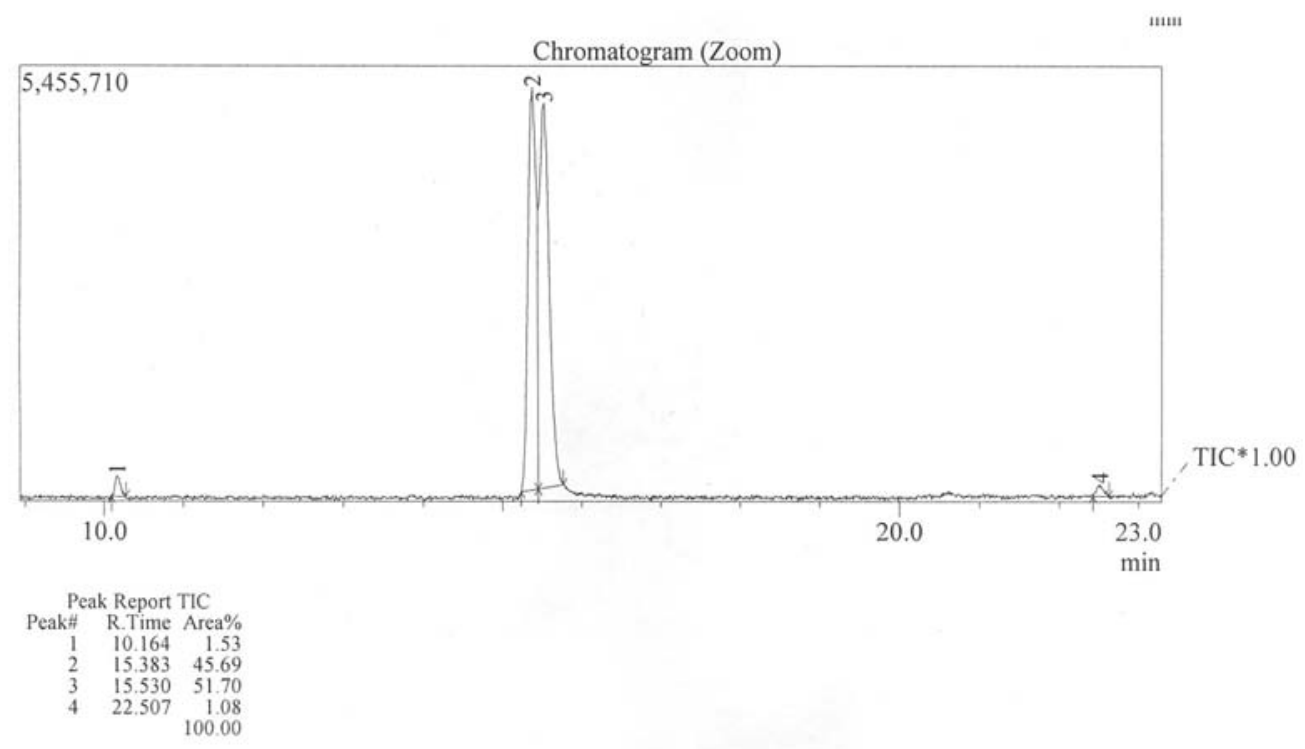

Peak \# 1: Reaction By-product Peak \# 2: $(R)$ or $(S)$-2-octanol Peak \# 3: $(R)$ or $(S)$-2-octanol

Figure S4. GC-MS chromatogram of $(R, S)$-2-octanol resolution mediated by the isolate UEA_014.

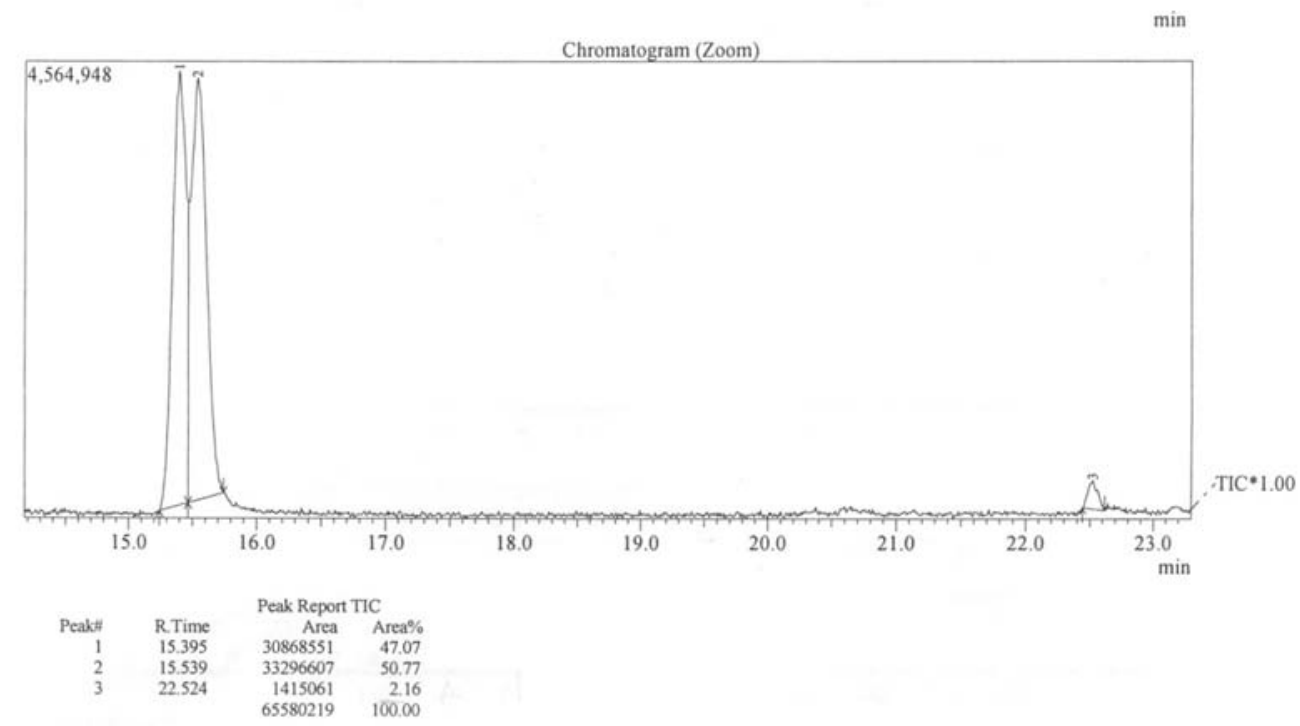

Peak \# 1: $(R)$ or $(S)$-2-octanol

Peak \# 2: $(R)$ or $(S)$-2-octanol

Peak \# 3: $(R)$ or $(S)$-1-methylheptil acetate

Figure S5. GC-MS chromatogram of $(R, S)$-2-octanol resolution mediated by the isolate UEA_023. 


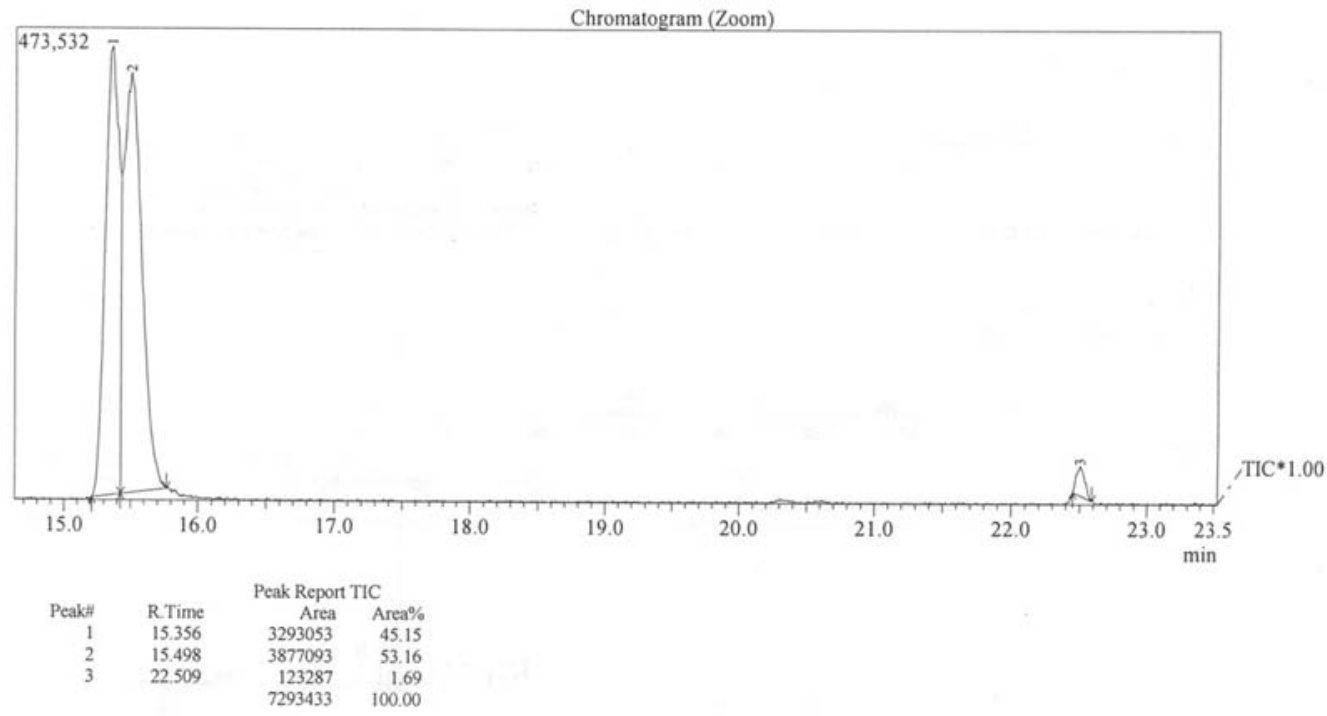

Peak \# 1: $(R)$ or $(S)$-2-octanol

Peak \# 2: $(R)$ or $(S)$-2-octanol

Peak \# 3: $(R)$ or $(S)$-1-methylheptil acetate

Figure S6. GC-MS chromatogram of $(R, S)$-2-octanol resolution mediated by the isolate UEA_027.

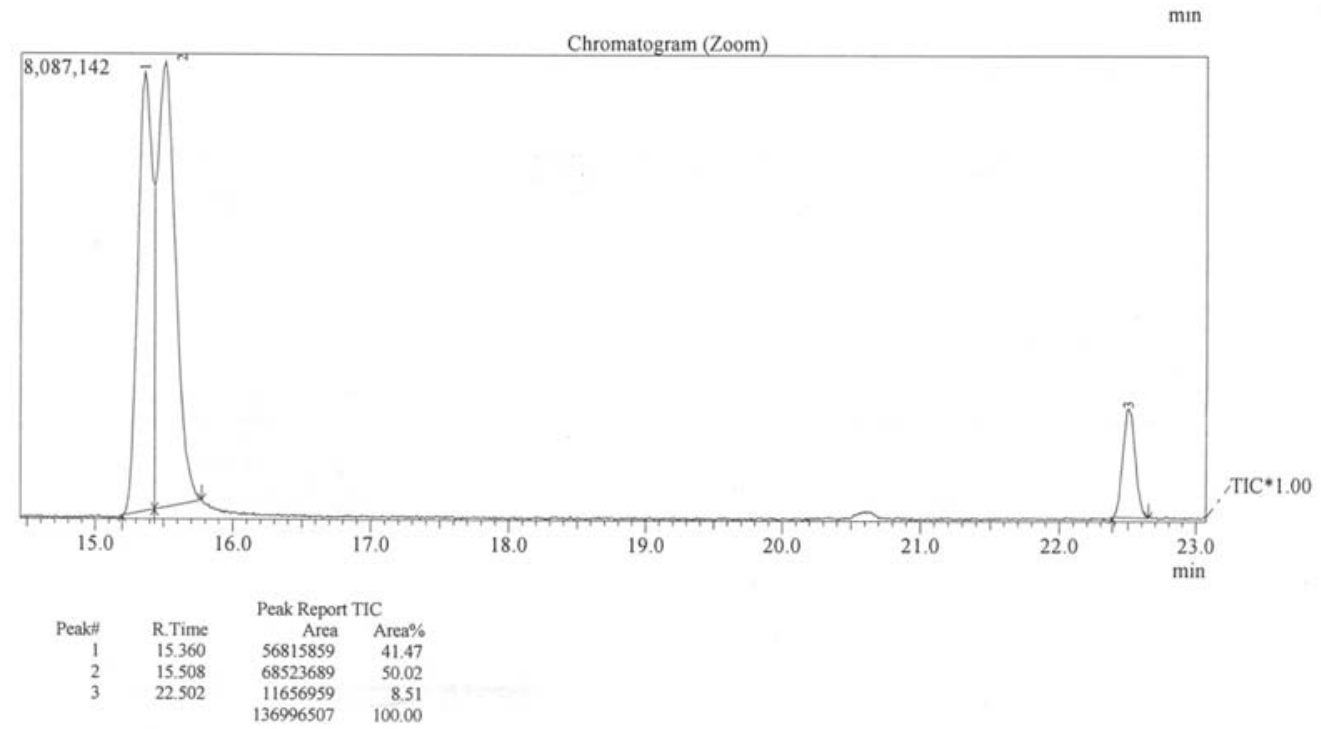

Peak \# 1: $(R)$ or $(S)$-2-octanol

Peak \# 2: $(R)$ or $(S)$-2-octanol

Peak \# 3: $(R)$ or $(S)$-1-methylheptil acetate

Figure S7. GC-MS chromatogram of $(R, S)$-2-octanol resolution mediated by the isolate UEA_041. 


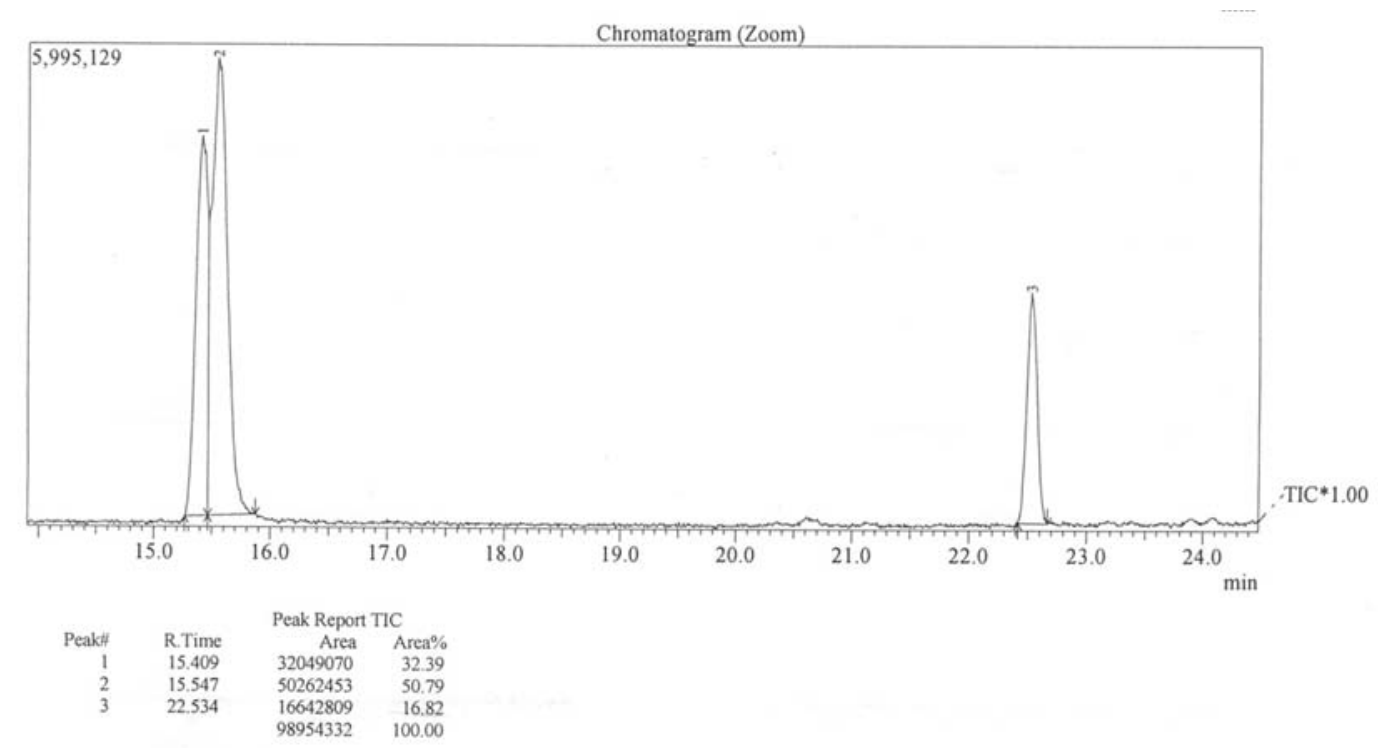

Peak \# 1: $(R)$ or $(S)$-2-octanol

Peak \# 2: $(R)$ or $(S)$-2-octanol

Peak \# 3: $(R)$ or $(S)$-1-methylheptil acetate

Figure S8. GC-MS chromatogram of $(R, S)$-2-octanol resolution mediated by the isolate UEA_053.

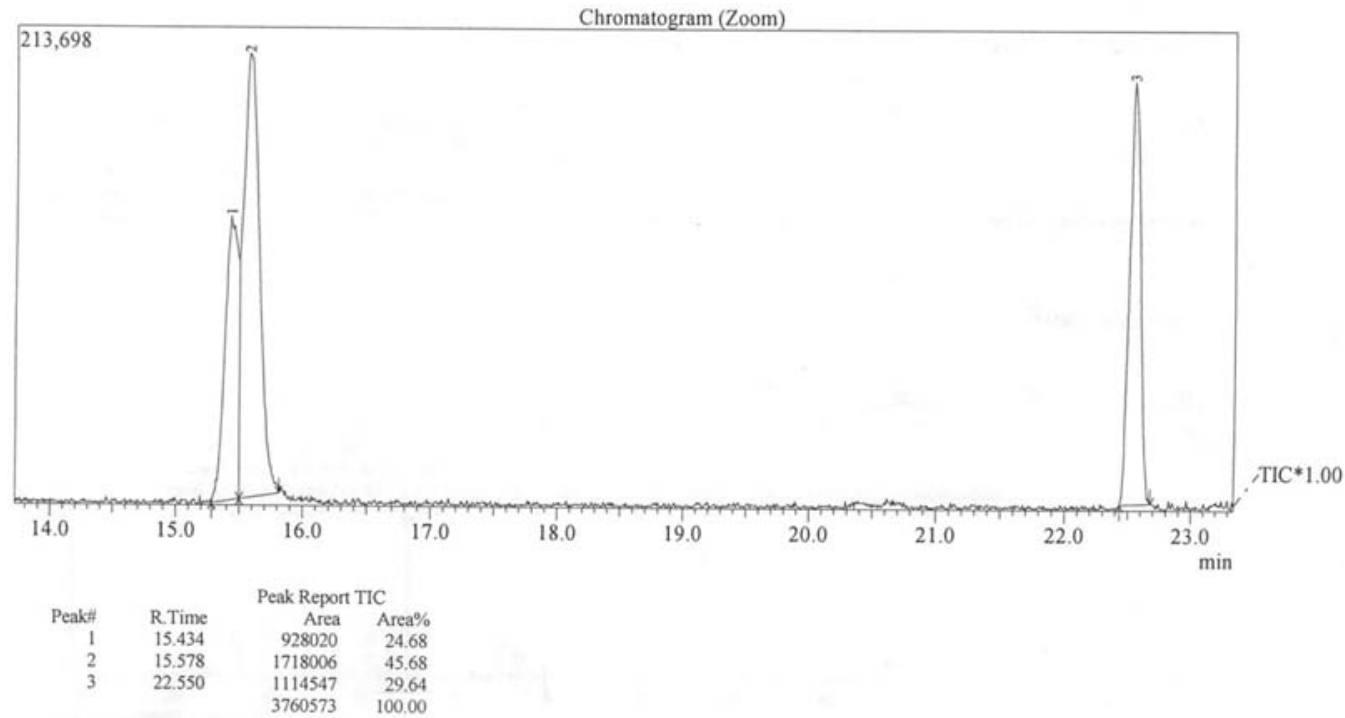

Peak \# 1: $(R)$ or $(S)$-2-octanol

Peak \# 2: $(R)$ or $(S)$-2-octanol

Peak \# 3: $(R)$ or $(S)$-1-methylheptil acetate

Figure S9. GC-MS chromatogram of $(R, S)$-2-octanol resolution mediated by the isolate UEA_115. 


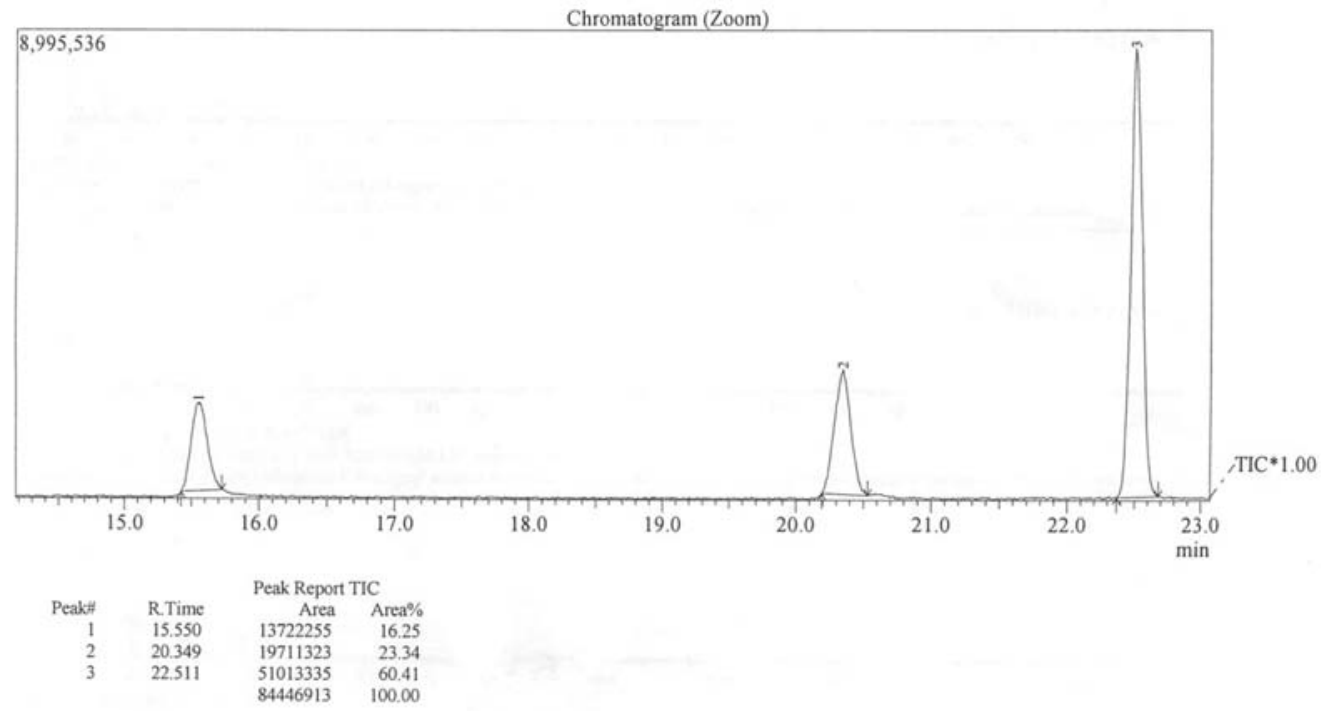

Peak \# 1: $(R)$ or $(S)$-2-octanol

Peak \# 2: $(R)$ or $(S)$-2-octanol

Peak \# 3: $(R)$ or (S)-1-methylheptil acetate

Figure S10. GC-MS chromatogram of $(R, S)$-2-octanol resolution mediated by the commercial enzyme Novozym 435 . 